\title{
Assessing the Impact of Renewable Energy on Regional Sustainability-A Comparative Study of Sogn og Fjordane (Norway) and Okinawa (Japan)
}

\author{
Valeria Jana Schwanitz ${ }^{1, *} \mathbb{C}^{\mathbb{D}}$, August Wierling ${ }^{1}$ and Payal Shah ${ }^{2}$ \\ 1 Department of Engineering and Natural Sciences, Western Norway University of Applied Sciences, \\ Campus Sogndal 6851, Norway; augustw@hvl.no \\ 2 Science and Technology Group, Okinawa Institute of Science and Technology Graduate University, \\ Okinawa Prefecture 904-0495, Japan; payal.shah@oist.jp \\ * Correspondence: valerias@hvl.no; Tel.: +47-5767-6125
}

Received: 7 September 2017; Accepted: 24 October 2017; Published: 28 October 2017

\begin{abstract}
The drive to expand renewable energies is often in direct conflict with sustainable development goals. Thus, it is important that energy policies account for potential trade-offs. We assess the interlinkages between energy, food, water and land, for two case studies, Okinawa and Sogn og Fjordane. We apply a range of assessment methods and study their usefulness as tools to identify trade-offs and to compare the sustainability performance. We calculate cross-sectoral footprints, self-sufficiency ratios and perform a simplified Energy-Water-Food nexus analysis. We use the latter for assessing scenarios to increase energy and food self-sufficiency in Okinawa, while we use ecosystem service (ESS) accounting for Sogn og Fjordane. For Okinawa, we find that constraints on the energy, food and water sectors urgently call for integrated approaches to energy policy; for Sogn og Fjordane, the further expansion of renewables comes at the expense of cultural and supporting ESS, which could outweigh gains from increased energy exports. We recommend a general upgrade to indicators and visualization methods that look beyond averages and a fostering of infrastructure for data on sustainable development based on harmonized international protocols. We warn against rankings of countries or regions based on benchmarks that are neither theory-driven nor location-specific.
\end{abstract}

Keywords: renewable energy; energy-water-food nexus; regional sustainability; regional sustainable development; integrated assessment; sustainability indicators; sustainable development data

\section{Introduction}

The reliable provision of clean, low-carbon energy is an integral part of any sustainable development agenda, since energy is a key component of economic and social progress. At the same time, the provision of energy often conflicts with sustainable development because energy production consumes resources and degrades the environment. Key trade-offs associated with renewable energy production and its distribution arise from footprints on water and land which is why an integrative, cross-sectoral approach to energy analysis is essential (cf. [1-8]). Many regions already face constraints in their land and/or water resources, which is likely to become more severe in the event of continued global warming [1,9]. Thus, hydropower competes with the supply of potable water; energy crops compete with food production and extensive land-use competes with the strive for intact nature. 
While the complex nature of the problem requires the use of detailed integrated assessment methods, the resources available within public administration for conducting such assessments are limited. Thus, there is a need for a more practical and efficient approach for assessing the integrated system perspective for energy planning. We illustrate such practical methods using two regional case studies of Okinawa and Sogn og Fjordane. We provide insights on how to approach the assessment of alternative regional scenarios envisioning the expansion of renewable energy and how to best account for potential conflicts between the energy, food and water sectors. For this purpose, we select a few assessment tools, namely cross-sectoral footprints, self-sufficiency ratios, energy-food-water nexus assessment, and ecosystem service accounting (ESS). Our analysis goes beyond identifying the current as well as the anticipated trade-offs arising from the expansion of renewable energies in the two case studies. By applying the set of analysis tools to two distinct regions, we also illustrate the difficulty of cross-comparisons and the problems with ranking regions (or nations) with respect to their sustainability performance.

We focus on the regional level of the sustainability problem for two main reasons. First, the regional scale is seldom studied (e.g., [10]). Generally, either the national scale is at the center of attention in global sustainable development analyses, often with the goal to convey a political message, e.g., as fostered through international agreements such as the Sustainable Development Agenda [11], or the local scale is considered when evaluating single undertakings such as the building of a wind power plant. However, the regional scale is the relevant scale, when one aims to assess whether the development is sustainable in general. It is the regional scale where national policies are put into action and where repercussions of local problems first become visible as they start to accumulate and potentially become an issue of global (systemic) relevance. Second, the regional scale is the scale which enables the bridging between macroeconomic top-down approaches targeting the evaluation of sustainability at the national level and bottom-up approaches that evaluate impacts at the local level. While the methods to analyze sustainable development at the regional level are yet to be standardized, the recent availability of detailed data and computational processing tools offer the possibility to test and further advance them. Indeed, reference [12] reviewing integrative approaches of the energy, water, and food nexus call for case study driven policy recommendations. This paper aims to contribute to this debate.

In the next section, we characterize the two regions that serve as our case studies-namely a Norwegian county, Sogn og Fjordane, and Japan's most southern prefecture, Okinawa (see Figure 1 for a map). We then describe the scenarios for the expansion of renewable energy in both regions (Section 2.1). Although the regions are different in many aspects such as climate, culture, and the current stresses on the environment, both are highly fragmented landscapes which enables us to identify the problems of sustainability assessments. We explore two alternative renewable energy scenarios for Sogn og Fjordane. In the first scenario, we consider a large expansion of renewable energy production (in particular, hydropower), whereas in the second scenario we consider a more moderate expansion by refraining from adding maximum possible capacities. For Okinawa, we analyze the two renewable energy scenarios that are envisaged by the prefectural government, but we extend them with different targets for food self-sufficiency, which is an important regional development issue in these remote Japanese islands. In Section 2.2, we provide an overview of the tools deployed, i.e., cross-sectoral footprints for energy, water and food, self-sufficiency ratios, energy-food-water nexus assessment ("nexus rapid appraisal" as shown in [13]) and ESS. In Section 3, we present the results. We first illustrate the results of the assessment of the current state of sustainability in both regions and then we evaluate the regional development scenarios for each region. For Okinawa we build on the nexus approach whereas for Sogn og Fjordane we use the ESS approach. In Section 4 we provide a general discussion on our insights from the assessments of the two case studies. We explain how to decide on the type of analyses required to assess scenarios that foster the expansion of renewable energies. Finally, we generalize the results and provide recommendations that can be taken up in practice and used for further development of theories for sustainable development. 


\section{Materials and Methods}

\subsection{Case Studies}

\subsubsection{Sogn og Fjordane (Norway) and Okinawa (Japan)}

We abstract from the problems of sustainable development in developing countries because both our case studies belong to highly developed nations. Figure 1 shows the geographic location of both case studies. Okinawa prefecture (Japan) is dominated by humid subtropical climate and the county of Sogn og Fjordane (Norway) is in the temperate and continental climatic zones. In Table 1, we present the geographic and climatic characteristics, economic overview and a list of important cultural and environmental assets associated with the two regions. All data points are provided for the year 2010 if not stated otherwise.
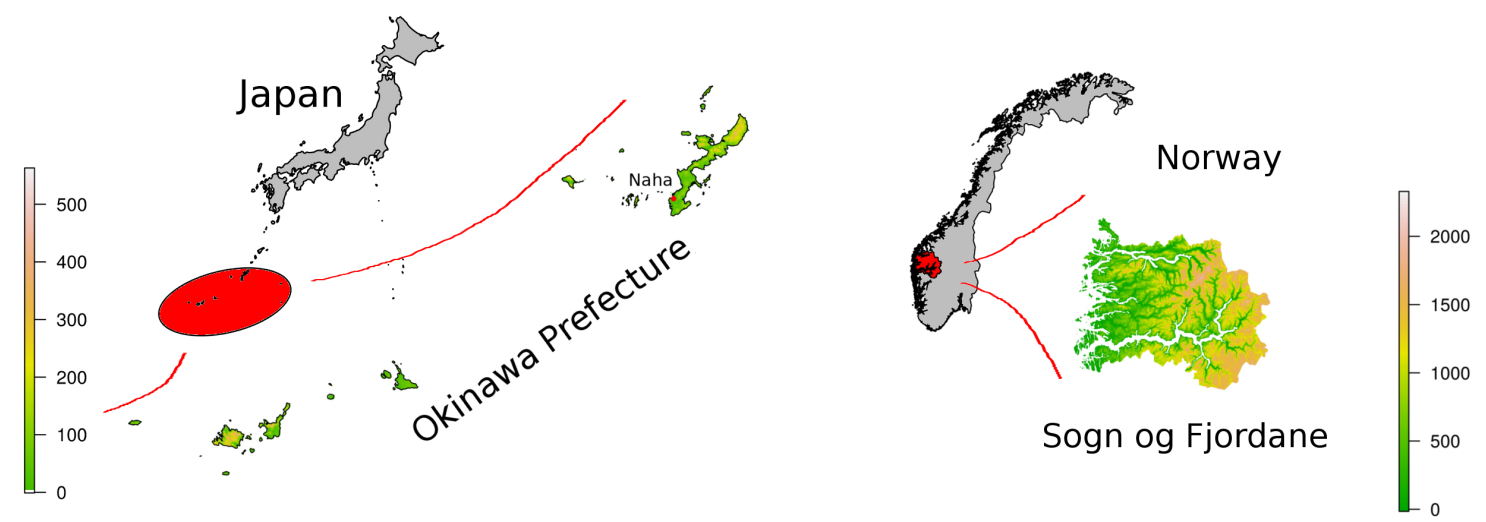

Figure 1. Geographic location of the two case studies: (left) Okinawa (Japan), (right) Sogn og Fjordane (Norway). The colors show the elevation profile in $\mathrm{m}$ (see legend).

Both Okinawa and Sogn og Fjordane are characterized by a high degree of geographic fragmentation. Okinawa consists of a chain of hundreds of islands that stretch over $1000 \mathrm{~km}$ and the landscape of Sogn og Fjordane is separated by steep mountains and deep fjords. Hence, both regions face similar challenges pertaining to the maintenance of infrastructure and the provision of services related to energy, water and food. While both have many areas which are remote and sparsely populated, population densities are significantly different between the two. Sogn og Fjordane covers an area that is eight times larger than Okinawa with a much smaller population of 110,000 inhabitants; Okinawa's population is 1.3 million inhabitants. In addition, almost a quarter of Okinawa's population lives in the metropolitan area of its prefectural capital, Naha, whereas the largest municipality of Sogn og Fjordane, Flora, has merely 11,400 inhabitants. In both regions, the agricultural sector is not the main contributor to the regions' GDP; instead, the service sector makes up the largest share of Okinawa's GDP and the industrial sector makes up the largest share of Sogn og Fjordane's GDP. Indeed, local food production in the Norwegian county declined by 8\% (2003-2013) [14]. Tourism, in particular, plays a notable role in both regions which is also underlined by the number of important world natural and cultural assets listed in their territories. Currently, the area under natural protection sums up to about 17\% and 30\%, for Okinawa and Sogn og Fjordane, respectively [15]. The most prominent difference between Okinawa and Sogn og Fjordane is the availability of freshwater. Sogn og Fjordane is water rich which - in combination with its landscape-enables large production capacities for hydropower. Sogn og Fjordane ranks second in electricity production among Norwegian provinces, exporting over half of its electricity production. In 2015 the county provided 12\% of the Norwegian electricity [16]. Okinawa, on the other hand, is partly water constrained [17-19], mainly owing to the small amount of 
water resources available per capita and the absence of large river networks on the main island and in the remote islands for effective transport of required water [20]. While Okinawa has a high annual precipitation, the topography of the island makes it difficult to retain the rainwater and much of the rainwater escapes into the sea. Additionally, the rapidly growing population accompanied by a spurt in tourism over the past few years has added to the water resource problem in Okinawa [21].

The constraints for Sogn og Fjordane mainly arise from climatic conditions, whereas Okinawa's regional development faces limitations of water, land, and energy availability. Both regions face similar challenges due to the high fragmentation of their landscapes, which at the same time are home to valuable, rare ecosystems. These valuable natural and cultural landscapes are partly threatened owing to a variety of reasons. Sogn og Fjordane's natural resources have been adversely affected by rapid socio-economic development and urbanization. For example, biodiversity, water and soil quality were negatively affected by the establishment of large hydropower capacities in the region [22-25] and by switching from traditional agricultural practices to an intensive agriculture relying on the heavy use of fertilizers and pesticides [26]. Okinawa's natural environment is also threatened by rapid socio-economic development, in addition to problems of high nutrient loads of soil and water [27,28], and red soil erosion that adversely affect the valuable coral reef systems of the islands [29]. Furthermore, large territories of the Okinawa mainland is occupied by the American military, adding to the problem of low availability of suitable land for the growing population and economy. Sogn og Fjordane on the other hand has to cope with increasing out-migration in remote areas, making it costly to maintain necessary services. At the same time, the few heavily populated areas attract a growing influx of population, posing problems similar to those of large Norwegian cities due to limited availability of flat terrain.

Table 1. Comparison of the main characteristics between the two sub-national case studies.

\begin{tabular}{|c|c|c|}
\hline Indicator & Okinawa & Sogn og Fjordane \\
\hline \multicolumn{3}{|c|}{ Geography and Climate } \\
\hline Area and population density & $2271.3 \mathrm{~km}^{2}, 622 \mathrm{cap} / \mathrm{km}^{2}$ & $18600 \mathrm{~km}^{2}, 6.1 \mathrm{cap} / \mathrm{km}^{2}$ \\
\hline Climatic zone [30] & Temperate warm-wet to subtropical (Cfa, Af) & $\begin{array}{l}\text { Temperate w/o dry season and warm } \\
\text { summer to cold with dry and warm summer } \\
\text { (Cfb \& Dsb) }\end{array}$ \\
\hline Fragmentation & $\begin{array}{l}5669 \mathrm{~km} \text { roads [31], constraint by remote } \\
\text { islands ( } 49 \text { inhabited), mountainous terrain, } \\
\text { high traffic congestion on main island, } \\
1 \text { international and } 12 \text { local airports }\end{array}$ & $\begin{array}{l}5364 \mathrm{~km} \text { roads [32], constraint by mountains } \\
\text { and fjords, } 5 \text { local airports }\end{array}$ \\
\hline Resources & $\begin{array}{l}\text { Affluent, partly water constraint and in } \\
\text { general resource constraint }\end{array}$ & $\begin{array}{l}\text { Affluent, water rich, resource constraint in } \\
\text { food production due to climatic conditions }\end{array}$ \\
\hline \multicolumn{3}{|c|}{ Economy } \\
\hline GDP & GDP [33]: 496 billion Yen ( $0.1 \%$ of Japan) & $\begin{array}{l}\text { Value added: } 20.4 \text { billion NOK ( } 2.4 \% \text { of } \\
\text { Norway): } 190512 \text { NOK per capita (excl. oil } \\
\text { and gas income) }\end{array}$ \\
\hline Key economic sectors & $\begin{array}{l}\text { Sectors (economy): services and tourism } \\
(26 \% \text { of GDP), government }(17 \%) \text {, real } \\
\text { estate industry (12\%), Sectors } \\
\text { (employment): wholesale and retail, } \\
\text { medical care, tourism; agriculture and } \\
\text { fisheries: } 1.9 \% \text {, energy: } 3.6 \%\end{array}$ & $\begin{array}{l}\text { Sectors ranking (value added): } 1 \text {. transport, } \\
\text { 2. construction, } 3 \text {. energy. Agriculture: } 4-10 \% \\
\text { (when including food processing), energy: } \\
10-11 \% \text { (when including oil and gas) }\end{array}$ \\
\hline Notable exported goods & $\begin{array}{l}\text { Notable exported goods: aquacultural } \\
\text { products, tropical vegetables and fruits, } \\
\text { beef and pork [34] }\end{array}$ & $\begin{array}{l}\text { Notable exported goods: electricity } \\
\text { (hydropower), aluminum items, fish and } \\
\text { agricultural products, fruits (10-64\% of } \\
\text { Norwegian produce) }\end{array}$ \\
\hline
\end{tabular}


Table 1. Cont.

\begin{tabular}{|c|c|c|}
\hline Indicator & Okinawa & Sogn og Fjordane \\
\hline \multicolumn{3}{|c|}{ Environmental and Cultural Heritage } \\
\hline $\begin{array}{l}\text { Protected } \\
\text { lands }\end{array}$ & $\begin{array}{l}\text { Wildlife Sanctuary }\left(87.3 \mathrm{~km}^{2}\right) \text {, Special } \\
\text { Protected Area [35] }\left(5.0 \mathrm{~km}^{2}\right) \text {, Natural } \\
\text { Protected Area: } 17 \%\end{array}$ & $\begin{array}{l}10 \text { sites IUCN sites (category V): } 2012.2 \mathrm{~km}^{2} \text {, } \\
\text { Natural Protected Area: 30\% }\end{array}$ \\
\hline Natural and cultural assets & $\begin{array}{l}\text { National Parks: Kerama Shotō }\left(935.95 \mathrm{~km}^{2}\right) \text {, } \\
\text { Iriomote Ishigaki }\left(205.7 \mathrm{~km}^{2}\right) \text {, Yanbaru } \\
\text { Forest }\left(136.22 \mathrm{~km}^{2}\right) \text {; Biodiversity hotspot } \\
\text { no. 33; Gusuku Sites and Related Properties } \\
\text { of the Kingdom of Ryukyu (UNESCO } \\
\text { World Heritage List No. } 972)\end{array}$ & $\begin{array}{l}\text { West Norwegian Fjords-Geirangerfjord and } \\
\text { Nærøyfjord (List No. 1195), National Parks: } \\
\text { Jostedalsbreen }\left(1310 \mathrm{~km}^{2}\right) \text {, with other } \\
\text { countries: Jotunheimen }\left(1151 \mathrm{~km}^{2}\right) \text {, } \\
\text { Breheimen }\left(1671 \mathrm{~km}^{2}\right) \text { Urnes Stave Church } \\
\text { (UNESCO World Heritage List no. } 58)\end{array}$ \\
\hline \multicolumn{3}{|c|}{ Main Expected Sustainability Challenges } \\
\hline $\begin{array}{l}\text { Socio-economic } \\
\text { dimension }\end{array}$ & $\begin{array}{l}\text { Ensuring self-sustaining development of } \\
\text { fragmented islands with intact nature, } \\
\text { avoiding subsistence economy }\end{array}$ & $\begin{array}{l}\text { Ensuring the future of rural regions as livable } \\
\text { places with intact nature; securing regional } \\
\text { food supply }\end{array}$ \\
\hline $\begin{array}{l}\text { Environmental } \\
\text { dimension }\end{array}$ & $\begin{array}{l}\text { Avoiding further fragmentation of the } \\
\text { landscape; red soil pollution of water, coral } \\
\text { reef bleaching, frequent constraints on } \\
\text { water usage during summer time and due } \\
\text { to increasing urbanization and agriculture } \\
\text { activities; adaptation to climate change } \\
\text { (securing stable water supply, coping with } \\
\text { heat waves and regular cyclones) water } \\
\text { and soil pollution }\end{array}$ & $\begin{array}{l}\text { Avoiding a further fragmentation of the } \\
\text { landscape; adaptation to climate change (acid } \\
\text { rain, invasion of non-native species and } \\
\text { vermins, risk of avalanches, mud slides, } \\
\text { strong precipitation events); need for more } \\
\text { sustainable agriculture and aquaculture } \\
\text { (spread of contaminants, eutrophication); } \\
\text { reversing impacts of hydropower production } \\
\text { (spoil heaps, physical changes to water } \\
\text { courses and channeling of water) }\end{array}$ \\
\hline
\end{tabular}

Overall, a key concern for regional development in both regions is securing an intact environment and avoiding further fragmentation of natural and cultural landscapes. Thus, there is a need for practical tools that enable the identification and assessment of trade-offs of different envisaged future pathways for achieving sustainable development that accounts for economic, social and environmental dimensions simultaneously. In the following sections, we test a number of such tools and evaluate their performances as assessment tools with the help of the two case studies.

\subsubsection{Scenarios for Expanding Renewable Energy Production in the Two Regions}

Okinawa. We conduct the analysis for the two energy scenarios as envisaged by the Okinawa Prefecture in its Energy Vision Action Plan (2013) [36]. The first scenario projects current trends in energy production into the future and is referred to as "Adapted scheme for energy supply and demand". The second scenario assumes a strong expansion of renewable energy production in particular, labeled as "Active promotion scheme of renewables" scenario. Based on the trend developments for the period from 1990-2012 for different economic sectors, the electricity demand for 2030 is projected to increase from 8.1 TWh per year to 8.4 TWh per year (not accounting for changes due to the electrification of the transport sector). As population dynamics is the most important driver for energy consumption in the residential sector; we use the national population projections of the prefecture [37] to compute the future energy demand in the residential sector. The Okinawa Energy Vision and Action Plan states that given the large offshore wind capacities for Okinawa, the prefecture's energy demand could easily be met by renewables. In scenario I, it is assumed that both, additional demand due to population and economic growth as well as the increase in demand due to a shift to electric transport $(+0.9 \mathrm{TWh})$, are met entirely by renewable energies. In addition, we assume that the electricity demand of remote islands will be fully supplied by renewables (representing $10 \%$ of the total electricity demand of the prefecture in 2030, i.e., $0.8 \mathrm{TWh}$ ). In total, renewables are expected to contribute about $2 \mathrm{TWh}$ to total electricity supply. This corresponds to a share of $10.2 \%$ of the renewables in primary energy. Alternately, in scenario II, we assume an additional increase of electricity use in the transport sector by $10 \%$ and a conversion of $20 \%$ to renewable electricity use for the whole prefecture. As a result, the total demand for generating electricity provided by renewables 
amounts to $3.8 \mathrm{TWh}$. This corresponds to a $20.4 \%$ share of renewables in the primary energy supply. Table 2 provides a breakdown of how the demand for energy can be met by different renewable energy technologies. It is surprising that solar PV is prominent for both scenarios given the large potential for offshore wind developments. In the more stringent energy scenario II, we assume that on-shore wind and ocean-based power production will increase considerably. Note that technologies are further specified for the following calculations and are given in the Supplementary Material, see Tables S1 and S2.

Okinawa faces severe constraints in the availability of land and freshwater resources; thus, an important goal for Okinawa is to improve energy and food self-sufficiency simultaneously. We specify two food scenarios in conjunction with the energy scenarios. The food scenarios are based on an expected population of about 1.432 million inhabitants in Okinawa in 2030 as compared to 1.393 million in 2010 [37]. We estimate the consumption of agriculture, livestock and aquaculture to increase proportionately to the increase in population. For both scenarios, the increase in food self-sufficiency from 2010 levels will entail increasing the land used for agricultural activities. For scenario I, we assume land use can only increase by $10 \%$ from 2010 levels of 17,203 ha for producing the required food. Thus, the land required under scenario I is 18,923 ha. In addition, while we still maintain the assumption of no exports for the "Adapted baseline" scenario, we assume any shortfall in production will be met through imports. Alternately, for scenario II, we assume there is no import or export of food to and from Okinawa. Hence, all agriculture, livestock and aquaculture products required for consumption are produced in Okinawa. Additionally, we assume there is no upper limit on how much new land is allocated for production of the required agriculture and livestock. Thus, the required land under scenario II is 20,946 ha (an increase of 22\% from 2010 levels). In Table 2, we summarize the key assumptions for the "Adapted baseline" and "Increased self-sufficiency" scenarios for the food and energy sectors.

Table 2. Scenarios for the provisioning of renewable energy and local food in Okinawa.

\begin{tabular}{|c|c|c|c|}
\hline & $\begin{array}{c}\text { Baseline Scenario } \\
\text { (2010) }\end{array}$ & $\begin{array}{c}\text { Scenario I } \\
\text { “Adapted Baseline" }\end{array}$ & $\begin{array}{c}\text { Scenario II } \\
\text { “Increased Self-Sufficiency }\end{array}$ \\
\hline \multicolumn{4}{|c|}{ Energy Sector } \\
\hline Electricity demand in TWh & 8.1 & 9.3 & 9.6 \\
\hline Renewables in primary energy [\%] & 0.5 & 10.2 & 20.4 \\
\hline \multicolumn{4}{|c|}{ Thereof [TWh] } \\
\hline Solar PV & 0.7 & 11.4 & 17.8 \\
\hline Wind & 0.2 & 2.0 & 6.3 \\
\hline Biomass & 0.4 & 0.5 & 1.8 \\
\hline Ocean Solutions & 0 & 0.3 & 2.7 \\
\hline \multicolumn{4}{|c|}{ Food Sector } \\
\hline Land conversion & & max. $+10 \%$ for agricultural area & no upper limit \\
\hline Trade in food & & excess demand met by import & no import or export of food \\
\hline Required food [Mt] & & 1.315 & 1.315 \\
\hline Land needed for food production [ha] & & 18,923 & 20,946 \\
\hline Required imports [1000 yen] & & $13,119,729$ & 0 \\
\hline
\end{tabular}

Sogn og Fjordane. We explore two alternative energy scenarios assuming that energy exports will continue to be a main pillar of the county's regional development. This is also in accordance with the National Energy Plan [38] which anticipates a strong growth in future electricity demand in Norway and Europe. The main features of the two energy scenarios are a commitment to a low-carbon transition, the expected full electrification of the transport sector and the envisaged contribution of Norway to balancing the fluctuations in renewable energy from wind and solar with the help of Norwegian hydropower reservoirs. In scenario I, which we refer to as the "Energy province", we assume an expansion in the production of renewable energy (i.e., hydropower, onshore wind and biomass) to the maximum extent possible, almost doubling current capacities to about $30 \mathrm{TWh}$ per year 
(see Table 3). In contrast, in the second scenario, which we refer to as "Waterfall province", we prioritize the value of pristine nature. In the second scenario, we only consider those hydropower plants for which concessions are already provided $(0.8 \mathrm{TWh})$ in the current annual production capacities of about 15.4 TWh in 2012. All the hydropower plans that we consider have capacities of less than $10 \mathrm{MW}$. Also, we assume that there is no expansion of energy production from wind or biomass in scenario II.

Table 3. Energy scenarios for Sogn og Fjordane envisioning the expansion of renewable energies [39] .

\begin{tabular}{ccccc}
\hline $\begin{array}{c}\text { Energy Production } \\
\text { (Electricity, No Fossil Fuels) }\end{array}$ & $\begin{array}{c}\text { Baseline } \\
\text { in GWh (2012) }\end{array}$ & $\begin{array}{c}\text { Potential for New Installed } \\
\text { Capacity in GWh }\end{array}$ & $\begin{array}{c}\text { Scenario I } \\
\text { "Energy Province" }\end{array}$ & $\begin{array}{c}\text { Scenario II } \\
\text { “Waterfall Province” }\end{array}$ \\
\hline Hydropower & 15364 & 6176 & 21540 & 16190 \\
Energy from wood & 233 & 1000 & 1233 & 233 \\
Energy from wind & 177 & 7293 & 7470 & 177 \\
Waste & 5.5 & $\mathrm{n} / \mathrm{a}$ & 5.5 & 5.5 \\
\hline Total in TWh & $\mathbf{1 5 . 8}$ & & $\mathbf{3 0 . 2}$ & $\mathbf{1 6 . 6}$ \\
\hline
\end{tabular}

\subsection{Methods}

An elaborate overview of each of the methods used in this study is beyond the scope of the paper. Instead, we provide a brief introduction supplemented by references to the related literature. The focus of the section is, however, on the provision of background information required to verify the calculations undertaken for our two case studies.

Figure 2 provides an overview on the tools selected for application to the case studies. As we will show in the following discussion, the initial set of tools (cross-sectoral footprints, self-sufficiency ratios, nexus rapid appraisal) were only partially able to identify anticipated trade-offs in the regions. This led us to continue the evaluation of the energy scenarios using the ESS approach for the case of Sogn og Fjordane, whereas we continued with the nexus rapid appraisal for the case of Okinawa.

\begin{tabular}{|c|c|c|}
\hline & Status quo analysis & Scenario analysis \\
\hline Okinawa $\sum$ & $\begin{array}{l}\text { Tools: Cross-sectoral footprints, } \\
\text { self-sufficiency ratios, nexus rapid }\rangle> \\
\text { appraisal, Result: Identification of } \\
\text { main trade-offs }\end{array}$ & $\begin{array}{l}\text { Continue assessment with: } \\
\text { Nexus rapid appraisal, decide } \\
\text { on benchmark }\end{array}$ \\
\hline Sogn og Fjordane $\sum$ & $\begin{array}{l}\text { Tools: Cross-sectoral footprints, } \\
\text { Self-sufficiency ratios, nexus rapid } \\
\text { appraisal, Result: Anticipated } \\
\text { trade-offs not clearly revealed }\end{array}$ & $\begin{array}{l}\text { Continue assessment with: } \\
\text { Ecosystem services accounting, } \\
\text { decide which to select }\end{array}$ \\
\hline
\end{tabular}

Figure 2. Evaluation tools applied in this publication to two case studies.

\subsubsection{Evaluation Tool: Cross-Sectoral Footprints}

Introduction. We focus on the interlinkages between "water for energy" (specifically, the production of electricity), "energy for food", "water for food" and the land required for energy, food and water. Note that we do not need to account for energy used in processing water/wastewater, since we assume the associated energy demand being included in the scenario assumptions. Furthermore, we focus on freshwater consumption which is likely to be most constrained. We do not look into use of seaor brackish water, either. The other interlinkages between the sectors are of minor concern for our case studies.

In general, a footprint is calculated by multiplying production with the footprint factor and time. Water-related footprints need to differentiate between water withdrawal and water consumption (see also [40]). The latter is the part that cannot be discharged. In case of the water footprint of energy, two indicators are commonly used, the water footprint of primary energy production and the water 
footprint of electricity. The most recent compilation of related footprint factors can be found in the World Energy Outlook 2016 [41] which builds on previous studies [42,43]. Reference [41] also provides a good overview on the topic. The factors for primary energy production depend on technologies to extract/mine, process, and transport the energy carriers. The highest footprint factors are associated with energy crops. For example, sugarcane ethanol production consumes between 2000-3,000,000 L per ton of oil equivalent (toe). Whereas fossil fuels range between 1-200,000 L per toe. The major amount is needed for mining [41]. Factors for electricity production, on the other hand, change with fuel, cooling technology, and turbine type. Among renewable technologies, the estimate of footprint factors for hydropower is highly site-specific and therefore commonly left out of general compilations, but [44] provides estimates on the global water footprint of hydropower. Most factors range between $10^{2}-10^{6} \mathrm{~L}$ per MWh. In comparison, solar PV is relatively more efficient with values between 5-100 L per MWh. Water used for agriculture (i.e., irrigation, food processing, transport, etc.) is the main component of the global water footprint. Indeed, according to sampling data from 1995-2005, consumption by the agricultural sector ranked highest within all countries and the total global water consumption in agriculture was $92 \%$ [40]. The actual water footprints of agriculture are region-specific and depend on the relative importance of the agricultural sector, the size of the agricultural production area, soil and groundwater conditions, weather conditions, efficiency of agricultural production and irrigation systems, and water management practices. In our analysis we focus on freshwater use only.

Energy has a wide range of uses in food production. It is required to work the soil, to irrigate the fields, to warm greenhouses and to process raw crops. A large amount of energy is also required for the production of fertilizers and pesticides used in agriculture. Reference [45] provides a state of the art review regarding energy intensity in agriculture and in food systems. We do not account for the energy used for producing the fertilizers and pesticides used in agriculture in Okinawa as these are fully imported. For the case of Sogn og Fjordane, the energy required for fertilizer and pesticide production is implicitly contained within the energy scenarios. Furthermore, we exclude energy required by the food processing industries for both regions.

Energy production requires land for a variety of uses; for example, large amounts of land are required for extracting resources for producing primary energy (i.e., mining activities) and establishing power plants and electricity transmission facilities. Among the renewable energy technologies, land is especially important for wind farms and hydropower installations. Also, the land requirements for growing biomass can be considerable. Overall, the land occupation by energy technologies is proportional to generation capacities. Thus, the land footprint of energy can be obtained from technology specific land-use efficiencies. A recent compilation of values for these land-use efficiencies is provided by [46]; Reference [46] also provides an introduction to the literature. Land-use efficiencies for hydropower plants are site specific and we use [21] for data on Norwegian installations.

Food production also requires land as an input. Land cover statistics provide a good approximation of available farmland. Additionally, spatially explicit information on farmland use is available from land cover surveys. Land-use efficiencies (i.e., footprint factors) for food production vary with the type of crop and the dietary traditions across nations. Also, differences in cultivation methods result in substantial variations in the production yields for a given area of agricultural land. Detailed statistics on this can be found in the national inventories as well as in the publications of the Food and Agriculture Organization of the United Nations (FAOSTAT). The latter also provides reports and studies that review the use of land for food production in detail. Land is also used in the provision of water. The amount required by water bodies is closely related to the geography and the local hydrological conditions. National land-use statistics and land cover surveys provide information on the amount of land covered by wetlands and freshwater bodies. The Global Climate Database [47] provides annual average and spatially explicit information on precipitation. Additionally, while regional statistics on water withdrawal are scarce, they are likely to become available in the near future with the further development of the Global Water Atlas [48]. 
Calculations in this study. We calculate the water-intensity of energy production in $\mathrm{m}^{3}$ per MWh and also provide estimates for absolute amounts of freshwater consumption by the energy sector in million $\mathrm{m}^{3}$. For Okinawa, annual freshwater withdrawal by water enterprises amounted to 187 million $\mathrm{m}^{3}$ in 2011 . The current yearly electricity demand is almost exclusively met with fossil fuel technologies with an installed capacity of about $2.2 \mathrm{GW}$ (of which $0.3 \mathrm{GW}$ is from gas turbines fueled with LNG, kerosene, heavy oil; $1.6 \mathrm{GW}$ is from steam turbines fueled with coal, LNG and heavy oil; and about $0.2 \mathrm{GW}$ is from diesel generators on the remote islands-see also the Supplementary Material Table S2). We exclude two major coal power plants from our calculations because they use seawater for cooling. Otherwise information on cooling mediums are not available. For some of the power plants, we lack data on the actual yearly output; we overcome this limitation by applying an average efficiency of $50 \%$ and an average capacity factor of 0.9 to roughly estimate actual production from installed capacities. Given our choice of parameters, we approximately meet the yearly electricity demand. Note that efficiencies of fossil technologies range between $0.3-0.6$. We take 0.5 and a capacity factor of 0.85 to match today's demand of about $8.1 \mathrm{TWh} / \mathrm{a}$, cf. [49]. Next, using technology- and fuel-specific water consumption factors in [50], we obtain the yearly water consumption rate. We restrict maximum water withdrawal to the total water withdrawal for the entire industrial sector. In the case of Sogn og Fjordane we only account for hydropower since it provides $98 \%$ of the total electricity production. Using the hydropower plant database [51] of the Norwegian Water Resources and Energy Directorate (NVE), we collect data on the yearly electricity production output and energy equivalents (i.e., footprint factors) for all plants in the county. The total water-use is roughly estimated at 20 billion $\mathrm{m}^{3}$.

Water-intensity of food production for Okinawa is obtained from the prefectural water statistics [52]. For Sogn og Fjordane, we obtain data on the withdrawal of water from communal water supply for agriculture [53]. Additionally, we also provide national values for the withdrawal of water from total renewable freshwater resources for food production [54] (refer to the number in Figure 3 for the water-food footprint given in brackets).

We estimate the energy-intensity of food production based on the electricity demand in agriculture. Additionally, we also provide the share of agriculture in final energy. We obtain the required data from the National Statistical Office of Norway for Sogn og Fjordane and from the Prefecture Statistics and the International Energy Agency [55] for Okinawa.

To calculate the land used to produce electricity in Okinawa, we use the land-use efficiencies for coal, gas, oil, wind, and biomass as provided in [46]. This factor multiplied with the currently installed capacities results in the total land footprint of energy production. To calculate the land used for hydropower in Sogn og Fjordane, we take the average of the occupied area per generated energy using the sample of Norwegian hydropower plants studied in [22]. We multiply this with the total generated electricity in Sogn og Fjordane to obtain the final estimate. The land taken by water and used for food is obtained from land-use statistics for Sogn og Fjordane [56] and from the National Numerical Land Information System [57] and the Statistical Yearbook of Japan for Okinawa.

\subsubsection{Evaluation Tool: Self-Sufficiency}

Introduction. We define self-sufficiency as the adequate provision of required quantity and quality of goods and services at any given point of time. Quantity sufficiency is achieved when demand can be met by supply. Quality sufficiency refers to the provision of healthy food, clean energy services and potable water. Economic sufficiency refers to the ability of inhabitants to purchase these services at affordable prices. The concept of food sufficiency is defined as "the extent to which a country can satisfy its food needs from its own domestic production" in [58]. Water self-sufficiency often focuses on quantity and affordability, and rarely focuses on issues of water quality. A typical indicator for self-sufficiency with respect to water quantity is the percentage of water withdrawn relative to available renewable water sources. This value, however, says little about the actual water stress levels, e.g., during different days of the year. Another commonly used indicator is the Falkenmark water stress indicator [59] which relates the available amount of water to the size of the population. The threshold 
level is set at $1700 \mathrm{~m}^{3} / \mathrm{cap} / \mathrm{a}$, thus values below the threshold are indicators of probable water shortages. Finally, a key component of any policy targeting self-sufficiency is the provision of sufficient quantities of clean energy. The expansion of renewable energies is particularly important as it reduces the dependence on external sources of energy (and provides a hedge against international markets) and simultaneously improves air quality (contributing to quality self-sufficiency criteria) [60]. The Global Energy Assessment Report ([49] ch. 5) provides an excellent introduction to issues pertaining to energy self-sufficiency.

Calculations in this study. All indicators for energy, food and water self-sufficiency used in this study are based on [11,61,62]. For energy self-sufficiency, we use the share of renewables in primary energy supply as a key indicator. For food self-sufficiency, we take the ratio of domestic food production to domestic consumption as the leading indicator and supplement this value with the food import-export ratio. The latter is not available at the county level for Sogn og Fjordane and hence we use national trade statistics [63] as a proxy. However, since Sogn og Fjordane is a main producer of pigs, goats, fish, fruits and potatoes, the national value is likely to be an upper bound compared to the regional value. A problem specific to Norway is the dominant role of fish products in exports. While the import-to-export ratio is 0.5 for all products, the corresponding number excluding fish is 8.1; this indicates that Norway is a major food importing country. We assume the latter ratio is more indicative of food self-sufficiency in Sogn og Fjordane. The import-to-export ratio for Okinawa is 6 based on the Statistical Yearbook of the prefecture [64]. We use the ratio of annual freshwater withdrawal to the total available freshwater resources as the leading indicator for water. We supplement this value with the Falkenmark water stress indicator.

\subsubsection{Evaluation tool: Nexus Analysis for Energy, Food, and Water}

Introduction. Based on a systematic exploration of inter-dependencies between the energy (E), water (W), and food (F) sectors, the EWF nexus strives to identify actual or possible trade-offs and synergies steered by sector specific policies in particular and societal developments in general. From a theoretical perspective, it recognizes a systems approach to cope with challenges of a world where resources, both socioeconomic and biophysical are limited. The basic idea of the EWF nexus is to unravel consequences of resource competition, whether it is competition between regions, or within a region, and identify alternative options for the use of a single resource. Thus, any EWF nexus analysis targets resource as well as economic efficiency. If the time horizon of future generations is also considered, the EWF nexus connects to the original idea of sustainability [65]. The various tools available for assessing the EWF nexus can be broadly categorized into two groups, integrated framework assessments cf. [6] and integrated modeling approaches cf. [66]. General introductions to the EWF nexus are provided in [67-71].

We follow the "nexus rapid appraisal" as outlined in $[6,13]$ which is based on commonly available indicators and which uses benchmarks derived from four country typologies: (1) Agriculture-based economy, dry country; (2) agriculture-based economy, water rich country; (3) affluent country, with natural resource constraints; and (4) transition country, experiencing strong population growth. As described in Table 1, Okinawa and Sogn og Fjordane mainly belong to country group (3). For this group, nexus interlinkages are examined with the help of selected indicators for five sustainability aspects: water, energy, food, labor, and capital (refer to Table 4 and the Supplementary Material, Table S1 for more details). The benchmark against which the two cases are assessed is derived from averaging a representative sample of countries that also belong to the country typology (3). These representative countries are Singapore, Japan, Lebanon, Korea, United Kingdom, Jordan, Jamaica, Israel, Armenia and Italy.

Calculations in this study. For each sustainability aspect, we use two indicators which are evaluated against a benchmark. The final score is a weighted average of the deviations of the indicators from the benchmarks [13]. Water sustainability is assessed based on the ratio of freshwater withdrawn to available renewable water resources (see Section 2.2.1). The benchmark for water sustainability 
is $40 \%$. The second water indicator that we can potentially use (as shown in [13]) is an indicator of the quality of water and requires information about the number of monitoring sites in agriculture with observations above pollution limits. This information is not available for Okinawa, hence we resort to using a single indicator for water (i.e., the ratio of freshwater withdrawn to available renewable water resources). For Sogn og Fjordane, we obtain data from national monitoring, but only a few observation points are available [72].

The first indicator for energy is the share of fossils in the total supply of primary energy with a benchmark of $88 \%$. The second indicator is the share of imports in the total primary energy supply with a benchmark of $80 \%$. In the case of Okinawa, both indicators have the same value, as Okinawa imports all its primary energy (all fossil resources). For Sogn og Fjordane, the national value is used to obtain the first indicator due to lack of data. The second indicator is zero as there are no imports. With respect to food the two indicators are: net import of agricultural products, food and live imports in $1000 \mathrm{I}$, and the change in cropland over the last 10 years. For the benchmark, we deviate from [13] because we were not able to verify their entries. Instead, we use Spain as a benchmark since the country is a main producer of a rich basket of foods in Europe throughout the year. Corresponding values are taken from FAOSTAT and national statistics (see Table 4). Labor is evaluated based on the share of active population in agriculture to overall economic active population and on the ratio of average earning in agriculture to the average earning in manufacturing. The benchmarks are $4.5 \%$ and 1.42 , respectively. For capital we use the total economic active population in agriculture versus the net production value of agriculture (benchmark: 0.096 per 1000 I\$) and the investment share in GDP (benchmark: 22.3\%) as performance indicators.

We make a few additional assumptions for calculating the scenario values for Okinawa. We assume that sugarcane production in the future is more efficient. To estimate the water consumption by tourists we assume that they consume almost three times more water than Okinawan residents and businesses [21]. Furthermore, we take the estimates of the Okinawa Convention and Visitor Bureau of an expected 12 million tourists per year in 2025 who will spend on average three days in Okinawa [73]. Additional water requirements based on a growing population are in line with the projected population estimates. For further details see Table 4 and the Supplementary Material, see Table S2.

\subsubsection{Evaluation tool: Ecosystem Services}

Introduction. Following the publication of the Millennium Ecosystem Assessment Report in 2005 [74], the concept of ecosystem services (ESS) has garnered the attention of researchers, planners, and decision makers and has been considered in important global policy development agendas such as the Aichi biodiversity targets [75]. A report focusing on Nordic countries was published in 2013 [76], suggesting a common methodology and providing the first empirical results at national level for Finland, Sweden, Norway, Denmark, Iceland and Nordic Islands. The idea of ESS is tied to societal decisions regarding the value of land depending on alternative options of its use. Theoretically, it means that every plot of land has a flag assigned signaling how different use options are prioritized by the society, i.e., which services the ecosystem of that property provides. Thus, the ESS approach has an anthropocentric focus. The designation of protected areas is an example of putting a value on land which is not directly related to economic activities. In other words, the ESS approach is an explicit recognition of the services provided by non-human and human nature. In 2001, the Norwegian Society decided to place a high value on the protection of land "without major infrastructure development" (known as INON [77]). This is documented in two parliamentary decisions [78,79], enacting a new, knowledge based system for biodiversity management. Until recently, it has been the basis to designate areas all over the country with a prioritized use. The information is publicly available and has been integrated into regional development plans (e.g., County Atlas Norway [80]). However, in 2014 the government revised its approach [81]. The INON concept will no longer be a "direct guiding criterion" but an "informative indicator". 
For Nordic countries, the classification of ecosystems is based on the CORINE Land Cover database [82] and the ecosystem classification of the NordBio 2010 project [83]. Services provided by ecosystems are grouped into four general categories and several subcategories, i.e., (1) provisioning; (2) regulating; (3) cultural and (4) supporting ecosystem processes and functions/habitat services [76]. For each of them, direct indicators and proxies have been identified. For example, for category (2) "regulating ecosystem services", there is a sub-category "pollination" with pollination capacity (based on species that need pollination, species pollinating, number of days available for flying etc.) as a direct indicator; and the number of nectar plants in the area as a possible proxy. The review provided in [84] is an example of a study which specifically focuses on ESS as connected to renewable energy production. Reference [85] argues that the application of the ESS approach to regional levels is particularly suitable.

Calculation in this study. We focus on a subset of ecosystem services (see Table 5 below) that are most affected by the expansion of hydropower, wind, and biomass $[22,76,84]$ in line with our scenario assumptions for Sogn og Fjordane. Next we explain the calculations for each of the sub-categories. For the category "provisioning ESS", the provision of energy is provided in the amount of GWh planned to be installed in each scenario (specified for hydropower, onshore wind, fuel wood, other biomass and waste). For the provision of food, we calculate the area in conflict with planned renewable energy locations, i.e., for the subcategory "aquaculture" it is the impact on area designated to salmon production and for the subcategories "reared animals" and "cultivated crops" it is the agricultural area affected. For cultural ESS we focus on hydropower and onshore-wind only, because the planned capacities are the highest for these two, indicating that they will dominate the impact on cultural ESS. We further account for the subcategories "use of nature for spiritual purposes" and "use of nature for recreational purposes". To identify this, specific locations for the planned power plants for onshore wind and hydropower are required. We obtain these data for onshore wind from the Regional Plan for the Expansion of wind power in Sogn og Fjordane [86] and for hydropower from a study by the Norwegian Water Resources and Energy Directorate [87]. For supporting ESS we account for the subcategories "maintenance and habitat services" (with a focus on INON impacts) and "maintenance and habitat services" (with a focus on biodiversity impacts). The calculations for the latter categories are obtained in the same way (refer to Supplementary Material Table S3). In the case of onshore wind, we built on [86] which provides an assessment of conflicts (low/middle/high) between envisaged wind power expansion and area categories (landscape, cultural heritage, INON, recreation activities/friluftsliv, biodiversity and agricultural). The study divides the area for potential wind power plants into 104 study sites (7\% of total area of Sogn og Fjordane). We map the area categories from this study to the corresponding EES subcategories. Note that despite the recent shift in emphasis with INON, the indicator is still of high importance for the assessment of Sogn og Fjordane, because wind development is envisaged in coastal areas. However, INON in coastal areas is still prioritized [81]. We next sum up all areas evaluated as being in high conflict (lower estimate) and in medium or high conflict (upper estimate). The final value given in Table 5 is obtained by relating this number to the total area of all study sites. In the case of hydropower, we use [87] and site-specific data on potential small hydropower developments provided by the Norwegian Water Resources and Energy Directorate [88]. These data specify the power plant locations including intakes for 737 potential developments. We utilize geospatial information on Sogn og Fjordane (see [77]) about designated areas for (a) landscape sites of national and regional importance; (b) cultural heritage of national and regional importance; (c) recreational activities of national and regional importance; (d) INON; (e) nationally important waters for salmon production; $(\mathrm{f})$ biodiversity and $(\mathrm{g})$ tourism. For each of them, we first count the number of intakes and power plants that overlap with these areas and then relate the result to the total number of planned developments. These shares provide us with the final estimates as shown in Table 5. 


\section{Results and Discussion}

\subsection{Sustainability Trade-Offs at Present_Comparing the Two Regions}

\subsubsection{Cross-Sectoral Footprints and Self-Sufficiency Ratios}

Figure 3 presents the main results for cross-sectoral footprints for both regions as well as self-sufficiency indicators as of 2010 (if not otherwise stated). The former are expressed in intensities, more specifically the consumption of electricity in agriculture, the amount of water needed for energy and food production, and the land required by the energy, food and water sectors. Self-sufficiency ratios for energy, food, and water are given as (a) the share of renewables in primary energy supply; (b) the share of renewables in electricity consumption; (c) the ratio of domestic food production to domestic consumption; (d) the food import-export ratio; (e) annual freshwater withdrawal as share of available freshwater resources and (f) yearly renewable water available per capita. Additionally, we provide the share of agriculture in final energy (refer to the number in brackets below the energy intensity of food production), the absolute amount of water used for energy production, the reserved land for nature protected area (NPA) and the share of built-up area.

The parameters for self-sufficiencies for Okinawa and Sogn og Fjordane with respect to energy, water and food only partly reveal the problems we expect to see (refer to Figure 3, 1.h.s. and r.h.s., respectively). Clearly, Okinawa has very low shares of renewables in energy production and since Okinawa is endowed with neither fossil resources nor Uranium, the indicators underline Okinawa's problem with respect to energy self-sufficiency. Energy is not an issue, however, for Sogn og Fjordane. With regard to water self-sufficiency, the share withdrawn from renewable resources is not a useful indicator for the case of Okinawa. However, water constraints on the island become apparent when we consider the Falkenmark threshold of $1700 \mathrm{~m}^{3}$ per capita per year. Indeed, Okinawa has experienced water shortages, especially in some of the remote islands as shown in Section 2.1. This regional disparity as well as the high water variability in a given year are not apparent from geographic and yearly averages. In contrast, due to the abundance of water resources, water self-sufficiency is not an issue for Sogn og Fjordane. Nevertheless, water quality, which is an issue for Sogn og Fjordane, is not depicted in the indicators. Water quality in the Norwegian county is adversely affected by high nutrient loads in groundwater and fjord waters due to overuse of fertilizers in agriculture. Furthermore, the large hydropower capacities also have a negative effect on the waterways due to their impact on ecosystems from changes in the natural waterways and from large deposits of material (spoil heaps). Thus, more detailed methods are needed to reveal these problems; this is our main motivation for using ESS for evaluating the energy scenarios for Sogn og Fjordane (see Section 3.2.2). Food self-sufficiency is similarly low in both regions (48\% vs. 56\% for Sogn og Fjordane and Okinawa, respectively). However, the value for Okinawa is of greater concern since it has a much larger growing season compared to Sogn og Fjordane. Indeed, the value of food imports exceeds exports by six times for Okinawa due to the strong focus on a few crops. This is comparable to Sogn og Fjordane, where the value of food imports is eight times higher than the value of food exports. However, this ratio changes drastically when we include the exports of fish products; for Norway, exports including fish products actually exceed imports by two times. Thus, again we see that a single indicator has relatively low explanatory power. Furthermore, despite the richer food basket produced in Sogn og Fjordane, agricultural production in the county is on decline in recent years.

The cross-sectoral footprints indicate that a substantially high amount of water is required for energy production in Sogn og Fjordane, owing to the county's heavy reliance on hydropower. However, it is misleading to compare this to Okinawa (where the water intensity of energy production is lower by 2600 times) without looking into additional background information. Indeed, the amount of water used in the energy sector in Okinawa amounts to as much as $70 \%$ of all industrial freshwater consumption. This shows the weaknesses of these indicators for comparing regions. Considering the high dependence on thermal power plants for electricity production in Okinawa, the high share 
of water use is reasonable since a large amount of water is consumed during the cooling processes. However, at least two coal based power plants on the Okinawa main island actually use seawater rather than freshwater for cooling purposes; the water use by these two coal plants have not been included in the estimates shown in Figure 3. The large amount of water used to produce food in Okinawa further underlines the stress on water resources on the island. Both regions show a low energy intensity of food production, owing to the relatively common application of energy efficient production methods and machinery. The general low share of energy for agriculture, resonates with the relatively low importance of the agricultural sector in the economy of both regions. For Sogn og Fjordane energy demands are dominated by demand from aluminum production. In the case of Okinawa, major energy consuming sectors are the commercial industry, food industry, residential consumption and transport [89]. Finally, the footprints of energy, food, and water are comparatively small—not pointing to a problem.
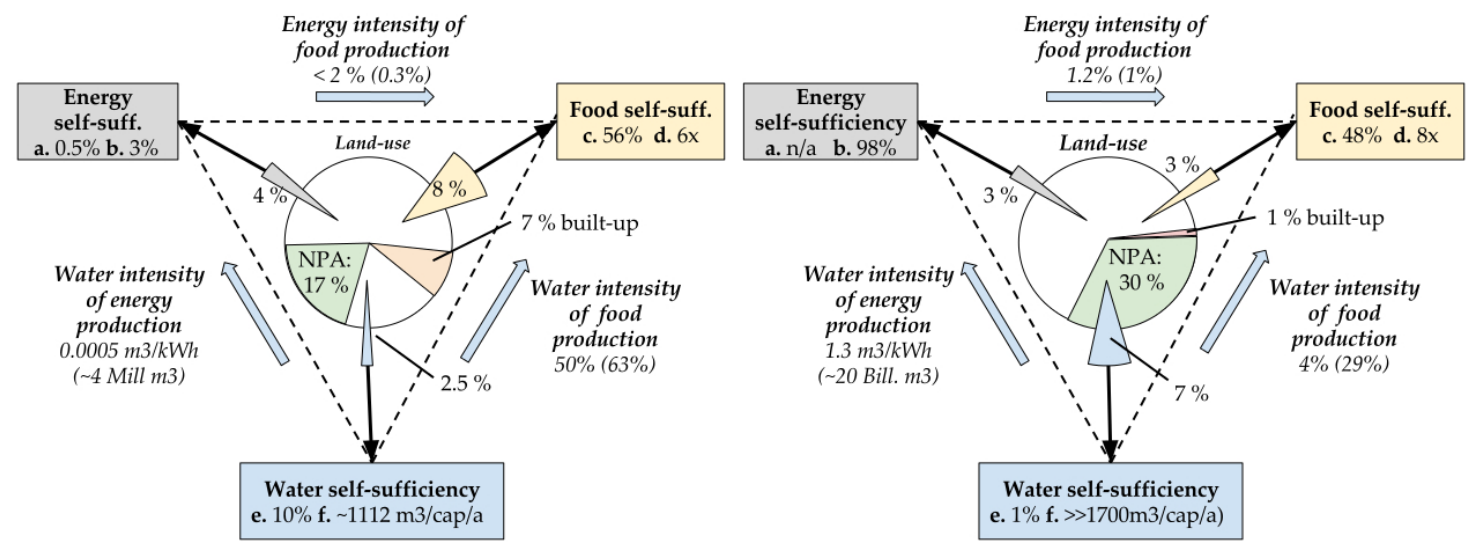

Figure 3. Cross-sectoral footprints and self-sufficiencies for energy, food and water in Okinawa (1.h.s.) and in Sogn og Fjordane (r.h.s.). Refer to main text for additional explanation.

\subsubsection{Energy-Food-Water Nexus Rapid Appraisal}

Table 4 presents selected sustainability indicators based on nexus rapid appraisal for both regions as suggested in [13]. We combine the scores of the performance indicators into one overall performance score for each of the five nexus aspects (energy, food, water, capital and labor). Figure 4 maps these final performance scores for Sogn og Fjordane and Okinawa against a benchmark performance score for affluent, partly resource constrained countries. To highlight the results of the nexus assessment, the benchmark has been arbitrarily fixed at position 6 in the plot for all dimensions. Deviations above this benchmark indicate potential problems with sustainable development. Refer to Section 2.2.3 for further details on this method.

According to Figure 4, food is an issue for Sogn og Fjordane. Alternately, in contrast to our expectations, this is not the case for Okinawa, since the overall score for food is slightly below the benchmark. This result is mainly driven by the averaging of the two food indicators (i.e., the net-imports per capita and the change in croplands). While the first indicator clearly raises concern, Okinawa performs well on the second indicator with a reduction in cropland area of $-4 \%$ compared to the benchmark of $-7.3 \%$. However, given the strong dependence of Okinawa on imports, this decline in cropland already poses a problem. With respect to water, both regions have values well below the benchmark, indicating that water is not a problem in either region. However, the benchmark for affluent countries assumes that a $40 \%$ withdrawal of water from renewable water resources is in accordance with sustainable management. Given the water problems in Okinawa, this benchmark appears too high and fails to identify potential issues. Furthermore, the benchmark is based on averaging across values over the control group. The nexus also includes an indicator on water quality. However, due to 
data limitations, we do not incorporate this indicator in our analyses. For Sogn og Fjordane, the data from the monitoring stations are insufficient to identify known issues with the overuse of fertilizers and pesticides.

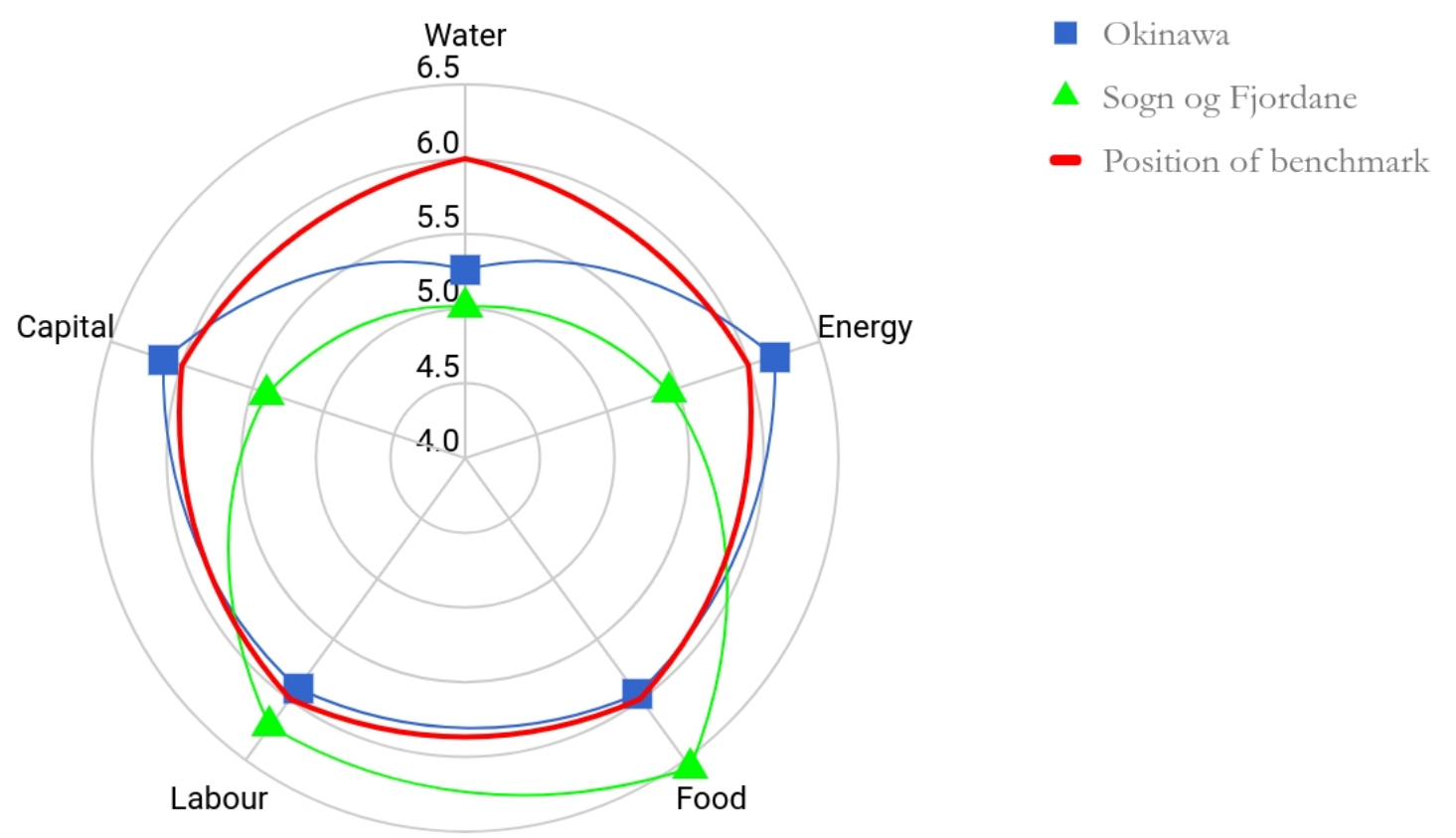

Figure 4. Nexus rapid appraisal for Okinawa and Sogn og Fjordane against the benchmark for affluent, partly resource constrained countries.

The nexus result for energy indicators is in line with our expectations. Sogn og Fjordane, an energy exporter, is below the threshold and Okinawa, with a heavy reliance on energy imports, is above the threshold. However, the graph does not illustrate the severity of the situation in Okinawa considering that the energy import dependency is extremely high ( $99.5 \%$ of resources required to produce energy are imported). This is a general problem of visualizing the indicators, since there is no obvious scale that enables an evaluation of the severeness of the problem. In addition, there is no common metric among the five sustainability dimensions used in the plot that would indicate a similar level of concern.

Two nexus aspects that explicitly refer to socio-economic sustainability are capital and labor. For Sogn og Fjordane, the findings are in line with expectations: investments continue to be high (also relative to the benchmark), but the two sub-indicators for labor reveal anticipated issues pertaining to unsustainable development. While the relative income from agriculture continues to increase, the overall population that relies on agriculture for livelihood is on the decline. Thus, the considerable subsidies from agriculture provide benefits for a smaller segment of the population. For Okinawa, the result is somewhat striking. The graph shows an issue with capital but not with labor. This is in contradiction to findings in [90] stating "Contrary to the general belief that arable land is extremely scarce and labor is underemployed in many pacific islands, including Okinawa, our field research reveals some convincing evidence that the chief scarcity factor is not land but labour".

We conclude the comparison of the current state of sustainability for our two case regions and proceed in the next section with the evaluation of the renewable energy scenarios. For Okinawa, we continue with the nexus rapid appraisal, whereas for Sogn og Fjordane, we proceed with ESS accounting. 
Table 4. Results for selected sustainability indicators for nexus rapid appraisal following FAO 2014.

\begin{tabular}{|c|c|c|}
\hline Sustainability Indicators & Okinawa & Sogn og Fjordane \\
\hline \multicolumn{3}{|c|}{ Water } \\
\hline $\begin{array}{l}\text { Freshwater withdrawal as share of total actual renewable } \\
\text { water resources }\end{array}$ & Average: 10\%, Miyako island: 51\% (JPN: 19\% [91]) & $0.7 \%$ \\
\hline $\begin{array}{l}\text { Share of monitoring sites in agricultural areas that exceed } \\
\text { recommended drinking water limits for } \mathrm{N}, \mathrm{P} \text { and } \\
\text { pesticides in surface and groundwater }\end{array}$ & $\mathrm{n} / \mathrm{a}$ & For Norway: none of the 58 sites are above the benchmark \\
\hline \multicolumn{3}{|c|}{ Energy } \\
\hline Contribution of fossil energy to energy supply & $\begin{array}{l}\text { 2010: } 99.5 \% \text { ( } 0.5 \% \text { from solar and biomass); } \\
\text { similar high dependence on fossil fuels for } \\
\text { electricity generation }\end{array}$ & $\begin{array}{l}2010 \text { [92]: } 65 \% \text { ( } 5 \% \text { biofuel, } 30 \% \text { hydropower); } \\
98 \% \text { of electricity comes from renewable resources } \\
\text { (most: hydropower) }\end{array}$ \\
\hline Energy imports & Net energy importer (coal, LNG, diesel) & Net energy exporter (electricity, oil, gas) \\
\hline \multicolumn{3}{|c|}{ Food } \\
\hline $\begin{array}{l}\text { Net import of agricultural products, food and live animals per } \\
\text { capita }\end{array}$ & $0.09 \times 1000$ I\$ p.c. $(J P N: 0.38 \times 1000$ I\$) [93] & NO: $0.48 \times 1000$ I\$ p.c. [94] \\
\hline Self-sufficiency & $\begin{array}{l}56 \% \text { in production value and } 34 \% \text { in caloric } \\
\text { value [95] }\end{array}$ & $\begin{array}{l}\text { Self-sufficiency [96]: Plant produce: fell from } 52 \% \text { to } 46 \% \\
\text { (2005-2013), Animal products: } 100 \% \text {, Seafood: } 100 \% \text { (net } \\
\text { exporter), self-sufficiency in NO: } 48 \% \text { in } 2010\end{array}$ \\
\hline Change in cropland use over the last 10 years & $-4.9 \%(2000-2010)[97]$ & $-8.3 \%(2003-2013)[98]$ \\
\hline \multicolumn{3}{|c|}{ Labor } \\
\hline $\begin{array}{l}\text { Total economic active population in agriculture/total } \\
\text { economic active population }\end{array}$ & 2010 [99]: 5\% & 2010 [100]: 7\% \\
\hline $\begin{array}{c}\text { Average earning in agricultural production versus average } \\
\text { earning in manufacturing }\end{array}$ & 2010 [101]: 0.41 & 2010 [102]: 0.30 \\
\hline \multicolumn{3}{|c|}{ Capital } \\
\hline $\begin{array}{l}\text { Total economically active population in agriculture/net } \\
\text { production value of agriculture }\end{array}$ & 2010 [103]: 0.051 per $1000 \mathrm{I} \$$ & 2015 [104]: 0.025 per $1000 \mathrm{I} \$$ \\
\hline Investment share in GDP (per respective sector) & $30-40 \%[105]$ & 2010 [106]: $10 \%$ \\
\hline
\end{tabular}




\subsection{Assessing Regional Scenarios for the Expansion of Renewable Energy}

\subsubsection{Increasing Energy and Food Self-Sufficiency Simultaneously in Okinawa}

The scenario analysis for Okinawa's renewable energy expansion is performed with the help of the nexus rapid appraisal [6,13]. Figure 5 maps the final performance scores for Okinawa for two future energy and food self-sufficiency scenarios against its current performance scores (see Table 4). Although Okinawa envisions an ambitious transition to renewable energies by a notable increase in installed capacities as shown in the figure, there continues to be a heavy dependence on fossil fuel for electricity production. Even in the more stringent scenario, $80 \%$ of the electricity is generated from fossil energy carriers. In case of scenario I, the land footprint of energy increases twofold, while it increased five-fold in case of scenario II. The largest shares are required by wood (above 40\%), sugarcane (above $20 \%$ ) and digestion gas (roughly 20\%) due to their high footprint factors. Even a 25-fold increase in solar PV to $1.8 \mathrm{TWh}$ only consumes $7 \%$ of the land required for energy production in the "Increased Self-Sufficiency Scenario". Clearly, by favoring solar PV over biomass production, the land-energy trade-off could be considerably reduced. An exception may be the use of next-generation multi-purpose crops such as sugar cane. A promising example is the new cultivar KY01-2044 which yields 1.5 times more biomass and contains 1.3 times more sugar even in poor environments [107]. Note that we have assumed this efficiency in the future scenarios.

With respect to food, Figure 5 reflects the prescribed food self-sufficiency improvements. However, the increase in the required area to achieve these targets reveals a serious concern when also accounting for the increased need of land for energy and continued urbanization. In the most stringent scenario the increase in land for food production amounts to $22 \%$ implying that roughly $10 \%$ of the total land area of Okinawa is used for that purpose (see also land-use data in Figure 3). Considering that the majority of inhabitants reside on the main island, a major portion of food and energy is required there. Since the main island comprises half of the prefecture's total land area, the achievement of self-sufficiency targets might come at the expense of the few forest areas that still exist in the southern and middle parts of the island. This raises concerns that the pressure to expand into current nature protected areas will be tremendous.
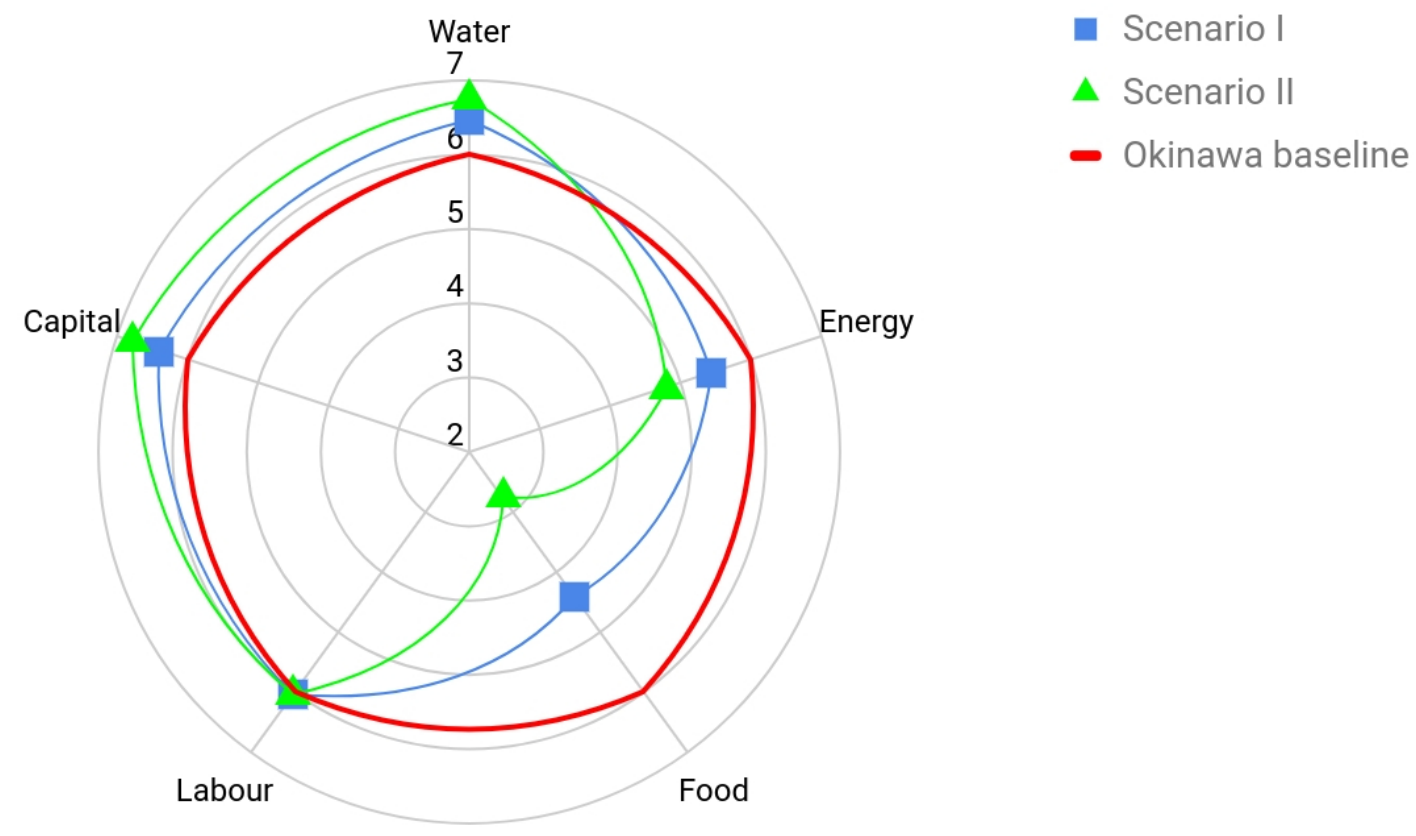

Figure 5. Nexus rapid appraisal for Okinawa's energy scenarios against the current benchmark. 
Water also comes under further pressure in the scenarios. In scenario II, Energy production accounts for a total of 5.4 million $\mathrm{m}^{3}$, representing an increase of $37 \%$ compared to the baseline. But the largest additional requirements for water are driven by food production (8-17 million $\left.\mathrm{m}^{3}\right)$, population growth $\left(4.4\right.$ million $\left.\mathrm{m}^{3}\right)$ and increasing tourism $\left(5.4\right.$ million $\left.\mathrm{m}^{3}\right)$. In light of these numbers, the additional amount of 1.4 million $\mathrm{m}^{3}$ of water for energy production is modest. Among the renewable technologies considered, sugarcane has the highest water footprint factor. However, given the dominance of solar PV in terms of planned installed capacities, it is solar PV that consumes the lion's share of $87 \%$ (scenario I) and $59 \%$ (scenario II).

In this study, we did not look into the energy required for water. While this is currently not an issue due to the increasing water scarcity, it might become an issue in the future when more energy will be needed to process water (e.g., for cleaning, recycling or desalination). Finally, we should point out that the small changes in capital arise from our assumed higher investments shares (per GDP) of $35 \%$ and $40 \%$, for scenario I and scenario II, respectively. These higher shares reflect the need of financing the renewable energy and food scenarios. The situation with respect to developments in labor are unchanged relative to the baseline, because the share of population employed in agriculture does not increase and the higher production volumes (and associated income) are entirely realized through gains in efficiencies.

\subsubsection{Expanding Renewable Energy Production in Sogn og Fjordane}

Next we discuss the results of the ESS accounting, focusing mainly on the "energy province" scenario since the changes will be most drastic for this scenario relative to the current condition (see Supplementary Material for both). The results are shown in Table 5. As expected, the provisioning ESS for energy increases notably due to the expansion of renewable energies from an annual capacity of 15.8 TWh to 30.2 TWh (an increase of 91\%). The impact of this large gain results in substantial losses for all other ESS. We focus on the impact on other ESS driven by the expansion of hydropower and onshore wind capacities, since these are the largest additional capacities planned. For the provisioning of food, we estimate that hydropower will affect salmon production since $3.3 \%$ of the possible 737 hydropower installations (either power plants or intakes) could be built within areas of national waters important for salmon production. Onshore wind is expected to impact the provisioning ESS for reared animals and cultivated crops, because up to $2-13 \%$ of the area is in direct conflict with important agricultural production areas. Hydropower as well as wind are likely to have a negative impact on cultural heritage landscapes. $5.3 \%$ of all hydropower plants are located in areas designated as important cultural heritage landscapes while $46 \%$ are located in areas important for recreational purposes. The conflict with cultural landscape ESS mainly arises from the fact that most of the heritage sites are located near the shoreline where the wind potential is commercial. Indeed, more than two thirds of the possible sites for onshore wind development are overlapping with cultural landscape areas of regional or national importance. We find similar conflicts in areas of high recreational importance. According to a previous study, all onshore wind and hydropower sites are likely to be in conflict with ESS related to tourism [86]. The supporting ESS "biodiversity" is also negatively affected by both renewable energies: $9.2 \%$ of all possible hydropower developments and $43-85 \%$ of wind development projects are expected in areas designated as important for biodiversity conservation. Given the high value ascribed to land that is free of human intervention (INON) by the Norwegian society, the negative impacts on the supporting ESS weighs strongly. While $45.6 \%$ of the potential hydropower developments are placed within a one kilometer radius of INON zones, $4.2 \%$ are located in the innermost INON zone (more than $5 \mathrm{~km}$ away from human intervention). The impact of onshore wind development expansion on supporting ESS are even larger such that $40-79 \%$ of the potential onshore wind farms are expected to be in conflict with INON zones. Besides reducing the ecosystem services in the affected areas, the development of the renewable energy capacities is likely to fuel a continued fragmentation of current intact ecosystems. 
Table 5. Results for Scenario I evaluation based on ESS accounting for Sogn og Fjordane. Abbreviations: RE—renewable energy, INON—area without of major infrastructure development.

\begin{tabular}{|c|c|c|c|c|c|}
\hline RE type & ESS & Division & Class & Indicator & Scenario I \\
\hline Hydropower & Provisioning & Food & Aquaculture & $\begin{array}{l}\text { Hydropower developments leading to damage in national } \\
\text { important waters for Salmon production in \% }\end{array}$ & 6.6 \\
\hline & & & Reared animals & Area in conflict with important agricultural area in $\%$ & 2 to 13 \\
\hline \multirow{2}{*}{ Biomass and waste } & & \multirow{2}{*}{ Energy } & Fuel wood & Yearly capacity in GWh & 1233 \\
\hline & & & Other, waste & Yearly capacity in GWh & 6 \\
\hline Hydropower & & & Hydropower & Yearly capacity in GWh & 21,540 \\
\hline Wind & & & Wind & Yearly capacity in GWh & 7470 \\
\hline Hydropower & Cultural & $\begin{array}{l}\text { Use of nature for } \\
\text { spiritual purposes }\end{array}$ & $\begin{array}{l}\text { Culture, heritage, identity, } \\
\text { spiritual capacity }\end{array}$ & $\begin{array}{l}\text { Hydropower developments leading to damage in } \\
\text { important landscape or cultural heritage landscapes in \% }\end{array}$ & 5.3 \\
\hline Wind & & & & $\begin{array}{c}\text { Area identified in conflict with } \\
\text { landscape and cultural categories in \% }\end{array}$ & 18 to 67 \\
\hline Hydropower & & $\begin{array}{l}\text { Use of nature for } \\
\text { recreational purposes }\end{array}$ & Recreational capacity & $\begin{array}{l}\text { Hydropower developments leading to a damage to } \\
\text { designated area for recreational purposes in } \%\end{array}$ & 46 \\
\hline Wind & & & & Area identified in conflict with recreational purposes in $\%$ & 11 to $41(100)$ \\
\hline Wind & & & & Area in conflict with INON in \% & 40 to 79 \\
\hline Hydropower & & & Impact on biodiversity & $\begin{array}{l}\text { Hydropower developments leading to a damage in areas } \\
\text { classified as important for biodiversity in \% }\end{array}$ & 9.2 \\
\hline Wind & & & & Change in area identified in conflict with biodiversity in \% & 43 to 85 \\
\hline
\end{tabular}




\section{Synthesis}

\subsection{Results for the Two CaseStudies}

Okinawa is a resource constrained island with limited land, water and energy resources, and this is apparent from the analysis carried out in Section 3. The parallel constraints on the energy, food and water sectors urgently call for integrated approaches to energy policy, accounting for cross-sectoral interlinkages. In particular, water could become the main bottleneck for further expansion of renewable energies, though this is an important goal given the continued high dependence on fossil resources even in the more ambitious scenario. Based on the scenario analysis, we find that at least one aspect of energy self-sufficiency could be substantially improved compared to the current baseline. Our results indicate that there is potential for significantly decreasing air pollution in Okinawa if (1) renewable energies replace existing coal power plants and (2) the transport sector undergoes electrification. Sustainable water management practices ranging from infrastructure investments in development of water reservoirs and transport systems to enable more efficient recycling of water can help alleviate the problems of water shortages, cf. [108]; the Pacific islands do not suffer from insufficient precipitation and, though costly, desalination technology can favorably ease the constraints faced by limited freshwater sources on land [109]. Alternately, renewable ocean technologies that do not rely on freshwater resources such as offshore wind power are also an option for continued expansion of renewable energy without impacting water. As the scenario analysis has shown, water scarcity could also undermine the achievement of energy and food self-sufficiency targets. Currently, Okinawa ranks 35th and 33rd among 47 provinces in Japan in terms of renewable shares in energy production and food self-sufficiency, respectively $[110,111]$. Yet, the potential for both is unexploited and Okinawa is far from reducing its stark dependence on fossil fuels. In order to achieve food self-sufficiency, Okinawa will not only have to allocate more land for agricultural activities, but also achieve cost efficiency and production efficiency in agriculture to compete with inexpensive agricultural imports (both from mainland and other countries) and potentially increase the agriculture income per worker which currently lags behind other sectors. The footprint of energy on land, however can be reduced by utilizing areas that are insufficient for food production (roof tops, former military bases, ocean area etc.). Our analysis also shows that the expansion of biomass production, mainly for the purpose of energy production, is counterproductive and should not be targeted. Furthermore, for the long term success of renewable energy, it needs to become competitive with existing fossil fuel based energy production. Solar PV and multi-purpose energy crops (e.g., sugarcane production) are good candidates for this. However, there is also a potential opportunity for Okinawa to achieve favorable advances in yet immature and non-commercial renewable technologies, as is evident on Kume island (which belongs to Okinawa prefecture). This small island with a population of about 8,000 inhabitants has proved itself a leader in Ocean Thermal Energy Conversion technology (OTEC) and recently installed the world's first notably large demonstration project of $100 \mathrm{~kW}$. Through the establishment of smart industrial symbiosis between OTEC and local businesses that make use of the cool, pure water in many ways, the island community is successfully exploring ways to increase economic efficiency since technical efficiencies are limited. For example, water remaining post electricity generation is re-used to lower the temperature of soil in nearby greenhouses enabling food production throughout the year. This also explains why the Energy Action Plan for Okinawa envisages a substantial built-up of OTEC capacities to about 88 GWh and 0.9 TWh, in scenarios I and II, respectively.

Sogn og Fjordane. The assessments based on cross-sectoral footprints, self-sufficiency ratios and EWF nexus analysis draw an overly positive picture of the general situation in Sogn og Fjordane and fail to show the anticipated trade-offs. This is mainly due to the fact that pressure on the three sustainability dimensions is relatively low in the whole county. The pressure on the environmental dimension is low owing to small population densities and abundance of water resources. The pressure on the socio-economic dimensions is also low since Norway (including Norwegian regions) is one of the countries with the highest welfare standards. Moreover, as shown in Section 2.2.4, the focus on 
the EWF nexus overlooks the values of land, pristine nature, biodiversity, and cultural lands, all of which are important dimensions, especially in the Norwegian context. The ESS approach can account for these values in addition to the valuation of the key resources considered in the EWF nexus; thus, we choose the ESS approach to assess renewable energy scenarios in Sogn og Fjordane. The study of ESS in Sogn og Fjordane shows that the large gains in the provisioning ESS due to the expansion of renewable energies results in substantial losses for all other ESS. In particular, supporting and cultural services may be reduced considerably. This resonates with the results in $[84,112]$ that study trade-offs from renewable expansion scenarios in the Alps. According to [84], the main affected ESS are those related to maintenance and habitat services (in particular for biomass, hydropower and wind developments), cultural services (in particular for wind and to some extent also for hydropower) and provisioning services of agricultural products. Reference [112] performs a multi-criteria analysis taking into consideration social, economic and environmental dimensions. The authors find that for the Alps region, biomass is found to be the best option, followed by hydropower development, whereas solar $\mathrm{PV}$ and wind power are found to be the worst alternatives. The reason for the lower scores of the latter are mainly due to their negative impacts on landscape aesthetics, land consumption and noise relative to the other alternatives.

A direct comparison of gains and losses requires a common metric, for which monetary equivalents are an option. However, uncertainty around such estimates are extremely large, especially because they require assigning monetary values to non-market activities (e.g., the value of landscape aesthetics). Such a study is left for future research, but we develop a rough approximation to provide an idea about the order of magnitude of such losses or gains. Assuming that electricity can be sold at the current electricity price of about $0.3 \mathrm{NOK} / \mathrm{kWh}$, the additional annual income amounts to about 4 billion NOK per year considering the total capacities of renewable energies added. Next, we use the results from a choice experiment performed in the Aurland municipality of Sogn og Fjordane [113] obtaining the total economic value of fjord and mountain agriculture. Specifying ecosystem services related to landscape, biodiversity, soil fertility and high quality local produce, the study broadly covers all the ESS categories that we have looked at in Section 3.2.2. The total economic value is estimated at 7143 NOK per person per year. Relating this value to the population of Sogn og Fjordane and an approximate number of 1.5 million tourists per year, we obtain roughly a monetary value of 11.4 billion NOK which is much higher than the anticipated revenues from energy sales. While these numbers are very rough estimates, they nevertheless show that the losses are likely to be of the same order of magnitude as the gains, and possibly even outweigh them.

We are aware of the limitations of our comparative study in which we had to rely on rough estimates and alternative proxies in many cases. In particular, the quantitative results only have illustrative power and cannot replace the depth and comprehensiveness of detailed sector studies for the different categories considered, implying that the numbers provided should not be used without consulting the original sources. Such a detailed analysis was not the purpose of our study. However, the work flow for evaluating the case studies presented in this paper is useful to identify current trade-offs of energy policy with sustainable development as well as those that potentially could arise in the envisaged future. Thus, we undertook the comprehensive exercise of looking into alternative sustainability assessment tools and applying them to both regions to learn about their usefulness as practical tools to identify trade-offs and to compare the sustainability performance of different locations. In addition to insights for each individual case study as summarized above, we gained some general insights on how to approach such sustainable energy assessments which we synthesize in the next section. 


\subsection{Synthesis of Insights and Recommendations}

The various analyses carried out serve as a useful starting point to assess energy developments from an integrated system perspective. It also became very clear that (renewable) energy policies need to be integrated into policy frameworks of other sectors such that trade-offs contradicting with sustainable development are not overlooked. However, none of the methods prove to be superior. Instead, results based on a combination of methods enabled us to develop a more coherent understanding of the individual case studies. Furthermore, we were able to identify the following limitations of the tools used in this study:

1. (a) All assessment tools demand a substantial amount of data which are often not available and, thus, compromises have to be made.

(b) In addition to the lack of data, there is also the problem of lack of harmonized data when comparing regions owing to differences in accounting methods.

2. The use of indicators based on averages is misleading and also not up to date given today's data technologies.

3. Benchmarks are futile if derived from a reference group and fail if local conditions are not accounted for.

4. A rigorous scientific understanding is a necessary but not a sufficient condition for achieving successful implementation in practice.

The lack of high quality, harmonized data is a serious issue (see also [43,71]), because these are a prerequisite for a quantitative analysis. Surely, the establishment of official statistical infrastructures is costly and takes time, let alone their harmonization across countries and regions. Nevertheless, there are good examples, such as the establishment of the UNFCCC greenhouse gas inventories [114], the setting up of EUROSTAT [115] (the statistical office of the European Union), cooperation on ESS accounting in the nordic countries [76,83], and also the recent initiatives to establish a United Nations Global Working Group (GWG) on Big Data for Official Statistics [116] and the Global Partnership for Sustainable Development Data [117]. Apart from establishing the official data infrastructures, it is also important to develop open data approaches, to share data and methods, and to deploy alternative sources of information (e.g., derived from geospatial information) wherever possible to test data quality.

The revolution in information technologies in the recent past makes it possible to develop indicators and visualization methods that look beyond averages by directly working with distribution functions [118]. Yet, the upgrade of tools used in research and practice lags behind. As evident from our analysis, indicators that are based on averages bear little meaning and are only interpreted correctly if additional background information is provided.

For example, two regions may exhibit the same outcomes of an indicator for very different reasons. Often, indicators are not able to capture the actual problem at hand, as seen in the case of water scarcity assessment for Okinawa. Indeed, the widespread use of averages (and the ranking of countries based on average indicators) is troublesome. It is impossible to account for concepts that are fundamental to sustainable development and to identify the multitude of causes leading to unsustainable development pathways using averages (e.g., fragmentation of ecosystems). Moreover, regions or countries where the density of population is low and societal development is high, will outperform areas where this is not the case. Such a "lead" in international rankings is not helpful, in particular when considering that most of today's environmental and social problems originate from unsustainable development pathways pursued by the highly developed nations. Their problems are underestimated and should therefore not serve as a reference point. Therefore, benchmarks are futile if derived from a reference group or- even worse-from the best performing countries. 
Instead of being artificial, benchmarks need to be location specific and based on rigorous science in order to properly assess the state of sustainability. This is indeed a difficult and complex task. However, research has progressed substantially in understanding the complex interlinkages between ecosystems. Several thresholds have been established at lower scales and attempts are being made for establishing national or even planetary level boundaries. In addition to the new scientific insights, the precautionary approach can provide a substitute for yet (or principally) unknown benchmarks, which is a method that is not new to planners and decision makers.

While scientific knowledge and the availability of high quality data are necessary to identify and monitor problems that can arise from neglecting the interlinkages between energy, water, food and other resources, the transaction costs of establishing monitoring systems and changing policy practices are high, cf. [70]. In other words, scientific understanding and data availability are only prerequisites and do not automatically lead to their implementation. Again, this suggests taking joint approaches, as coordination can lower overall transaction costs. In our study, we also ignored the problems with the (non-)functioning of institutions. Besides not being in focus, this problem is a minor issue in the two regions, but in general it cannot be ignored. We also did not look into the role of stakeholders, or how the responsibilities to manage resources are set up, cf. [119]. Yet, considering the high stakes of private entities in their function as landowners or major investors, the inclusion of their perceptions is of high relevance for the design of sustainable energy policies [9]. This is left to future research.

\subsection{Conclusions}

As revealed by our case studies assessing the interlinkages between energy, food, water and land, the expansion of renewable energies can be in direct conflict with sustainable development goals. Thus, it is pertinent to use integrated cross-sectoral assessment when designing energy scenarios. We identified that for Okinawa, water could become the main bottleneck when expanding renewable energy and food self-sufficiency in the remote Japanese islands. In Sogn og Fjordane, we find that the three tools applied (i.e., cross-sectoral footprints, self-sufficiency ratios and EWF nexus analysis) are insufficient to reveal the anticipated trade-offs, because pressure on the three common sustainability dimensions is relatively low due to small population densities and abundance of water resources in the Norwegian county. Here, the ecosystem system services (ESS) approach is the better choice. We find that the further expansion of renewables comes at the expense of cultural and supporting ESS, which could outweigh gains from increased energy production.

Relevant general insights follow from our comparative assessments. Most important, the use of indicators and benchmarks based on averages is misleading as a tool to assess trade-offs within a region but also when comparing different regions (or nations). We urgently recommend a general upgrade to methods that look beyond averages and a fostering of infrastructure for data on sustainable development based on harmonized international protocols. We warn against rankings of countries or regions based on indicators and benchmarks that are neither theory-driven nor location-specific.

Supplementary Materials: The following are available online at www.mdpi.com/2071-1050/9/11/1969/s1, Table S1: Comparative nexus analysis, Table S2: Scenario analysis Okinawa, and Table S3: Scenario analysis Sogn og Fjordane.

Acknowledgments: The research leading to these results has received funding from the Norwegian Research Council under grant agreement No. 238281, Renewable Energy Projects: Local Impacts and Sustainability (RELEASE). V.J.S. also acknowledges support from the Okinawa Institute of Science and Technology Graduate University (OIST) during a research stay in 2017. OIST and the Western Norway University of Applied Sciences covered the costs to publish in open access.

Author Contributions: All authors have shaped and discussed the research design and case study results. P.S. and V.J.S. (A.W. and V.J.S.) collected empirical data from Okinawa (Sogn og Fjordane). V.J.S. and A.W. carried out the analysis. A.W. and P.S. contributed to writing the paper; V.J.S. coordinated the study and wrote it.

Conflicts of Interest: The authors declare no conflict of interest. 


\section{References}

1. Edenhofer, O.; Pichs-Madruga, R.; Sokona, Y.; Seyboth, K.; Matschoss, P.; Kadner, S.; Zwickel, T.; Eickemeier, P.; Hansen, G.; Schlömer, S.; et al. IPCC Special Report on Renewable Energy Sources and Climate Change Mitigation; Cambridge University Press: Cambridge, UK; New York, NY, USA, 2011.

2. Reisch, L.; Eberle, U.; Lorek, S. Sustainable Food Consumption: An Overview of Contemporary Issues and Policies. Sustain. Sci. Pract. Policy 2013, 9, 7-25.

3. Olsson, G. Water, energy and food interactions-Challenges and opportunities. Front. Environ. Sci. Eng. 2013, 7, 787-793, doi:10.1007/s11783-013-0526-z.

4. Giampietro, M.; Aspinall, R.J.; Ramos-Martin, J.; Bukkkens, S.G.F. Resource Accounting for Sustainability Assessment. In The Nexus Between Energy, Food, Water and Land Use; Routledge: London, UK; New York, NY, USA, 2014.

5. IRENA. Renewable Energy in the Water, Energy \& Food Nexus. 2015. Available online: http:/ /www.irena.org/ documentdownloads/publications/irena_water_energy_food_nexus_2015.pdf (accessed on 30 August 2017).

6. Smajgl, A.; Ward, J.; Pluschke, L. The water-food-energy Nexus-Realising a new paradigm. J. Hydrol. 2016, 533, 533-540, doi:10.1016/j.jhydrol.2015.12.033.

7. Gasparatos, A.; Doll, C.N.H.; Esteban, M.; Ahmed, A.; Olang, T.A. Renewable energy and biodiversity: Implications for transitioning to a Green Economy. Renew. Sustain. Energy Rev. 2017, 70, 161-184, doi:10.1016/j.rser.2016.08.030.

8. Hertwich, E.G.; Gibon, T.; Bouman, E.A.; Arvesen, A.; Suh, S.; Heath, G.A.; Bergesen, J.D.; Ramirez, A.; Vega, M.I.; Shi, L. 2014 Integrated life-cycle assessment of electricity-supply scenarios confirms global environmental benefit of low-carbon technologies. Proc. Natl. Acad. Sci. USA 2015, 112, 6277-6282, doi:10.1073/pnas.1312753111.

9. Pachauri, R.K.; Meyer, L.A. (Eds.) Climate Change 2014: Synthesis Report. In Contribution of Working Groups I, II and III to the Fifth Assessment Report of the Intergovernmental Panel on Climate Change; IPCC: Geneva, Switzerland, 2014; 151p.

10. Smetana, S.; Tamásy, C.; Mathys, A.; Heinz, V. Sustainability and regions: Sustainability assessment in regional perspective. Reg. Sci. Policy Pract. 2015, 7, 163-186, doi:10.1111/rsp3.12068

11. Sustainable Development Agenda-Knowledge Plattform. Available online: https://sustainabledevelopment. un.org/?menu=1300 (accessed on 28 August 2017).

12. Al-Saidi, M.; Elagib, N.A. Towards understanding the integrative approach of the water, energy and food nexus. Sci. Total Environ. 2017, 574, 1131-1139, doi:10.1016/j.scitotenv.2016.09.046.

13. FAO. Walking the Nexus Talk: Assessing the Water-Energy-Food Nexus in the Context of the Sustainable Energy for All Initiative. 2014. Available online: http://www.fao.org/3/a-i3959e.pdf. (accessed on 21 August 2017).

14. Eldby, H.; Fjellhammer, E. Norsk Jordbruk, Raport 8/2014. Available online: http:/ /www.agrianalyse.no/ file=3394 (accessed on 26 August 2017).

15. Computed from the World Database on Protected Area. Available online: https://www.iucn.org/theme/ protected-areas / our-work/world-database-protected-areas (accessed on 29 August 2017).

16. Statistics Norway. Available online: https://www.ssb.no/statistikkbanken/SelectVarVal/saveselections.asp (accessed on 26 August 2017).

17. Yamauchi, H.; Miwa, N.; Morita, D. Spatial Imbalance and Institutional Issues of Water Resources Management In Okinawa, Japan. Water Int. 1989, 14, 128-134, doi:10.1080/02508068908692075.

18. Carlsen, J.; Butler, R. Island Tourism: Towards a Sustainable Perspective, 8th ed.; CABI Publishing: Wallingford, UK, 2011.

19. Gassert, F.; Landis, M.; Luck, M.; Reig, P.; Shiao, T. Aqueduct Global Maps 2.1; Working Paper; World Resources Institute: Washington, DC, USA, 2014. Available online: http:/ /www.wri.org/publication/aqueduct-globalmaps-21 (accessed on 28 August 2017).

20. Prefectural Water Statistics for Okinawa. Available online: http://www.pref.okinawa.jp/site/kikaku/ chiikirito/chiikishinko/kentyoukimizujyukyukeikaku.html (accessed on 26 August 2017).

21. Kamiya, D. Regional Vulnerability in Okinawa Prefecture. In Coping with Regional Vulnerability: Preventing and Mitigating Damages from Environmental Disasters; Kamiya, D., Hagihara, K., Asahi, C., Eds.; Springer: Tokyo, Japan, 2016, doi:10.1007/978-4-431-55169-0_5. 
22. Bakken, T.H.; Aase, A.G.; Hagen, D.; Sundt, H.; Barton, D.N.; Lujala, P. Demonstrating a new framework for the comparison of environmental impacts from small- and large-scale hydropower and wind power projects. J. Environ. Manag. 2014, 140, 93-101, doi:10.1016/j.jenvman.2014.01.050.

23. Kålås, J.A.; Henriksen, S.; Skjelseth, S.; Viken, Å.E. Environmental Conditions and Impacts for Red List Species; Norwegian Biodiversity Information Centre: Trondheim, Norway, 2010.

24. Evju, M.; Hassel, K.; Hagen, D.; Erikstad, L. Small-Scale Hydropower Plants and Rare Bryophytes and Lichens; Knowledge and Lack of knowledge, NINA Report 696; Norsk Institutt for Naturforskning: Trondheim, Norway, 2011; p. 33.

25. Bakken, T.H.; Sundt, H.; Ruud, A.; Harby, A. Development of Small Versus Large Hydropower in NorwayComparison of Environmental Impacts. Energy Procedia 2012, 20, 185-199, doi:10.1016/j.egypro.2012.03.019.

26. For Example, Ammonia Use Exceeded the National Target by $13 \%$ in 2016. Statistics Norway. Available online: https:/ / www.ssb.no/en/natur-og-miljo/statistikker/agassn/aar-forelopige/2016-05-23 (accessed on 26 August 2017).

27. Kawahata, H.; Ohta, H.; Inoue, M.; Suzuki, A. Endocrine disrupter nonylphenol and bisphenol A contamination in Okinawa and Ishigaki Islands, Japan-Within coral reefs and adjacent river mouths. Chemosphere 2004, 55, 1519-1527, doi:10.1016/j.chemosphere.2004.01.032.

28. Statistics Norway, Kommunale Avløp. 63/2013. Available online: https://www.ssb.no/natur-og-miljo/ artikler-og-publikasjoner/_attachment/153599?_ts=142e1befaf8 (accessed on 1 September 2017).

29. Roy, K. Water resources in relation to major agro-environmental issues in Japan. J. Dev. Sustain. Agric. 2007, 2, 27-34, doi:10.11178/jdsa.2.27.

30. Kottek, M.; Grieser, J.; Beck, C.; Rudolf, B.; Rubel, F. World Map of the Köppen-Geiger climate classification updated. Meteorol. Z. 2006, 15, 259-263, doi:10.1127/0941-2948/2006/0130.

31. Road Statistics Okinawa. Available online: http://www.pref.okinawa.jp/site/doboku/dorokan/ documents/h25douroshisetsugenkyoutyousyo.pdf (accessed on 21 August 2017).

32. Road statistics Sogn og Fjordane. Available online: https://statistikk.fylkesatlas.no/statistikk/4d5a40b3db28-46d8-b389-e496b0772e36 (accessed on 21 August 2017).

33. Prefectural Statistics. Available online: https://web.archive.org/web/20130913123113 (accessed on 21 August 2017).

34. Prefectural Trade Statistics. Available online: http://www.pref.okinawa.jp/site/shoko/asia/hanro/ tradeokinawah24.html (accessed on 23 August 2017).

35. Wildlife Sanctuary Statistics for Japanese prefectures. Available online: https://www.env.go.jp/nature/ choju/area/pdf/area2-2.pdf (accessed on 21 August 2017).

36. Okinawa Energy Vision Action Plan 2013. Available online: http://www.pref.okinawa.jp/site/shoko/ seisaku/kiban/h22enerugibijonkouhyou.html (accessed on 25 August 2017).

37. National Institute of Population and Social Security Research, Future Estimated Population by Region in Japan. Available online: http://www.ipss.go.jp/pp-shicyoson/j/shicyoson13/t-page.asp (accessed on 26 August 2017).

38. National Energy Plan Norway 2030. Available online: https://www.regjeringen.no/contentassets/ 31249efa2ca6425cab08130b35ebb997/no/pdfs/stm201520160025000dddpdfs.pdf (accessed on 26 August 2017).

39. The Norwegian Water Resources and Energy Directorate, NVE. Available online: https://www.nve.no/ Media/5153/foldn2013.pdf. (accessed on 28 August 2017).

40. Hoekstra, A.Y.; Mekonnen, M.M. The water footprint of humanity. Proc. Natl. Acad. Sci. 2012, 109, 3232-3237, doi: 10.1073/pnas.1109936109.

41. International Energy Agency. World Energy Outlook; OECD/IEA: Paris, France, 2016. Available online: https:// www.iea.org/publications/freepublications/publication/WorldEnergyOutlook2016ExcerptWaterEnergyNexus. pdf (accessed on 29 August 2017).

42. Macknick, J. A Review of Operational Water Consumption and Withdrawal Factors for Electricity Generating Technologies; National Renewable Energy Laboratory: Golden, CO, USA, 2011.

43. International Energy Agency. World Energy Outlook; OECD/IEA: Paris, France, 2012. Available online: http: //www.worldenergyoutlook.org/media/weowebsite/2012/WEO_2012_Water_Excerpt.pdf (accessed on 29 August 2017).

44. Scherer, L.; Pfister, S. Global Water footprint assessment of hydropower. Renew. Energy 2016, 99, 711-720, doi:10.1016/j.renene.2016.07.021. 
45. Pelletier, N.; Audsley, E.; Brodt, S.; Garnett, T.; Henriksson, P.; Kendall, A.; Kramer, J.K.; Murphy, D.; Nemecek, T.; Troell, M. Energy Intensity of Agriculture and Food Systems. Annu. Rev. Environ. Resour. 2011, 36, doi:10.1146/annurev-environ-081710-161014.

46. Trainor, A.M.; McDonald; R.I.; Fargione, J. Energy Sprawl is the Largest Driver of Land Use Change in United States. PLoS ONE 2016, 11, doi:10.1371/journal.pone.0162269.

47. Global Climate Database. Available online: http://worldclim.org (accessed on 31 August 2017).

48. Provided by the World Resource Institute. Available online: https://www.wri.org/our-work/project/ aqueduct (accessed on 31 August 2017).

49. GEA. Global Energy Assessment-Toward a Sustainable Future; Cambridge University Press: Cambridge, UK; New York, NY, USA, 2012. Available online: http:/ / www.globalenergyassessment.org/ (accessed on 29 August 2017).

50. Behrens, P.; van Vliet, M.T.H.; Nanninga, T.; Walsh, B.; Rodrigues, J.F.D. Climate Change and the vulnerability of electricity generation to water stress in the European Union. Nat. Energy 2017, 2, 17114, doi:10.1038/nenergy.2017.114.

51. Hydropower Plant Database. Available online: https://www.nve.no/energiforsyning-og-konsesjon/ vannkraft/vannkraftdatabase/vannkraftverk/?id=10 (accessed on 29 August 2017).

52. Statistics Provided by the Prefectural Government of Okinawa. Available online: http:/ /www.pref.okinawa. jp/site/kikaku/chiikirito/chiikishinko/kentyoukimizujyukyukeikaku.html (accessed 28 August 2017).

53. Statistical Office Norway. Available online: https:/ / www.ssb.no (accessed on 31 August 2017).

54. FAOSTAT Yearly Statistics. Available online: http://www.fao.org/docrep/018/i3107e/i3107e.PDF (accessed on 28 August 2017).

55. Data from the International Energy Agency. Available online: https://www.iea.org/publications/ freepublications/publication/EnergyEfficiencyIndicatorsHighlights_2016.pdf (accessed on 28 August 2017).

56. SSB, Table 09594. Available online: https://www.ssb.no (accessed on 31 August 2017).

57. GIS Data. Available online: http://nlftp.mlit.go.jp/ksj-e/gml/datalist/KsjTmplt-L03-a.html (accessed on 31 August 2017).

58. Clapp, J. Food self-sufficiency: Making sense of it, and when it makes sense. Food Policy 2017, 66, 88-96, doi:10.1016/j.foodpol.2016.12.001.

59. Falkenmark, M. The massive water scarcity threatening Africa-why isn't it being addressed. Ambio 1989, 18, 112-118. Available online: jstor.org/stable/4313541?seq=1\#page_scan_tab_contents (accessed on 31 August 2017).

60. Schwanitz, V.J.; Longden, T.; Knopf, B.; Capros, P. The implications of initiating immediate climate change mitigation-A potential for co-benefits? Technol. Forecast. Soc. Chang. 2015, 90, 166-177, doi:10.1016/j.techfore.2014.01.003.

61. Reytar, K.; Hanson, C.; Henninger, N. Indicators of Sustainable Agriculture: A Scoping Analysis; World Resources Institute: Washington, DC, USA, 2014. Available online: http:/ / www.worldresourcesreport.org. (accessed on 31 August 2017).

62. OECD. Self-sufficiency Indicators. In Society at a Glance 2005: OECD Social Indicators; OECD Publishing: Paris, France, 2005.

63. SSB. Table 08809. Available online: https://www.ssb.no (accessed on 31 August 2017).

64. Statistical Yearbook of Okinawa Prefecture. Available online: http://www.pref.okinawa.jp/toukeika/ yearbook/yearbook54.html (accessed on 31 August 2017).

65. WCED. Our Common Future, World Commission on Environment and Development; Oxford University Press: Oxford, UK, 1987.

66. Bazilian, M.; Rogner, H.; Howells, M.; Hermann, S.; Arent, D.; Gielen, D.; Steduto, P.; Mueller, A.; Komor, P.; Tol, R.S.J.; et al. Considering the energy, water and food nexus: Towards an integrated modelling approach. Energy Policy 2011, 39, 7896-7906, doi:10.1016/j.enpol.2011.09.039.

67. Biggs, E.M.; Bruce, E.; Boruff, B.; Duncan, J.M.A.; Horsley, J.; Pauli, N.; McNeill, K.; Neef, A.; Van Ogtrop, F.; Curnow, J.; et al. Sustainable development and the water-energy-food nexus: A perspective on livelihoods. Environ. Sci. Policy 2015, 54, 389-397, doi:10.1016/j.envsci.2015.08.002.

68. Bhaduri, A.; Ringler, C.; Dombrowski, I.; Mohtar, R.; Scheumann, W. Sustainability in the water-energy-food nexus. Water Int. 2014, 40, 723-732, doi:10.1080/02508060.2015.1096110 
69. Sanders, K.T.; Masri, F.S. The energy-water agriculture nexus: the past, present and future of holistic resource management via remote sensing technologies. J. Clean. Prod. 2016, 117, 73-88, doi:10.1016/j.jclepro.2016.01.034.

70. Wichelns, D. The water-energy-food nexus: Is the increasing attention warranted, from either a research or policy perspective? Environ. Sci. Policy 2017, 69, 113-123, doi: 10.1016/j.envsci.2016.12.018.

71. Kurian, M. The water-energy-food nexus. Environ. Sci. Policy 2017, 68, 97-106, doi:10.1016/j.envsci.2016.11.006.

72. European Environmental Agency. Available online: http://www.eea.europa.eu/data-and-maps/exploreinteractive-maps/overview-of-soe-monitoring-stations (accessed on 31 August 2017).

73. Projection by OCVB. Available online: http:/ /english.ryukyushimpo.jp/2016/01/06/24265/ (accessed on 31 August 2017).

74. Millennium Ecosystem Assessment. Ecosystems and Human Well-being: Synthesis; Island Press: Washington, DC, USA, 2005. Available online: https:/ /www.millenniumassessment.org/documents/document.356.aspx. pdf. (accessed on 31 August 2017).

75. For More Resources, See Publication on 'The Economics of Ecosystems and Biodiversity (TEEB)'. Available online: http: / www.teebweb.org/our-publications/all-publications / (accessed on 31 August 2017).

76. Argimon, M.; Badura, T.; D'Amato, D.; Kettunen, M.; Kinnunen, S.; Vihervaara, P. Socio-Economic Importance of Ecosystem Services in the Nordic Countries: Synthesis in the Context of the Economics of Ecosystems and Biodiversity (TEEB); Nordic Council of Ministers: Copenhagen, Denmark, 2014, doi:10.6027/tn2012-559.

77. Norwegian Environment Agency. Reduction in Encroachment-Free Area. Available online: https:// kartkatalog.miljodirektoratet.no/MapService/Details/inon?lang=en-us (accessed on 31 August 2017).

78. Stortingsmelding 42 (2000-2001) on Biological Diversity. Available online: https://www.regjeringen.no/en/ dokumenter/report-no.-42-to-the-storting-2000-2001 (accessed on 31 August 2017).

79. Stortingsmelding 26 (2006-2007) on Governmental Policy towards the Environment and the State of the Environment in Norway. Available online: https:/ / www.regjeringen.no/en/dokumenter/report-no.-26-tothe-storting-2006-2007 (accessed on 31 August 2017).

80. County Atlas Norway. Available online: https:/ / www.fylkesatlas.no/ (accessed on 31 August 2017).

81. Utmarkskommunenes Sammenslutning USS (Association of Norwegian Municipalities). Available online: utmark.no/node5817 (accessed on 28 August 2017).

82. CORINE Land Cover Database by the European Environmental Agency. Available online: https://www.eea. europa.eu/publications / COR0-landcover (accessed on 28 August 2017).

83. Normander, B.; Levin, G.; Auvinen, A.-P.; Bratli, H.; Stabbetorp, O.; Hedblom, M.; Glimskär, A.; Gudmundsson, G.A. State of Biodiversity in the Nordic Countries. An assessment of Progress Towards Achieving the Target of Halting Biodiversity Loss by 2010; TemaNord 2009:509; Nordic Council of Ministers: Copenhagen, Denmark, 2009.

84. Hastik, R.; Basso, S.; Geitner, C.; Haida, C.; Poljanec, A.; Portaccio, A.; Vrščaj, B.; Chris Walzer, C. Renewable energies and ecosystem service impacts. Renew. Sustain. Energy Rev. 2015, 48, 608-623, doi:10.1016/j.rser.2015.04.004.

85. Tammi, I.; Mustajärvi, K.; Rasinmäki, J. Integrating spatial valuation of ecosystem services into regional planning and development. Ecosyst. Serv. 2016, 1-15. doi:10.1016/j.ecoser.2016.11.008.

86. Regional Plan for Vindkraft; Sogn og Fjordane Fylkeskommune: Hermansverk, Norway, 2010.

87. Beregning av Potensial for Små Kraftverk i Norge, Torodd Jensen (Red.); NVE Report 19; NVE: Oslo, Norway, 2004.

88. Norwegian Water Resources and Energy Directorate. Available online: https://gis3.nve.no/link/?link= smakraft (accessed on 31 August 2017).

89. Agency of Natural Resources and Energy. Available online: http://www.enecho.meti.go.jp/statistics/total_ energy / results.html (accessed on 31 August 2017).

90. Kakazu, H. Island Sustainability: Challenges and Opportunities for Okinawa and Other Pacific Islands in a Globalized World; Trafford Publishing: Bloomington, IN, USA, 2012.

91. World Development Indicators Knoema Database. Available online: https://knoema.com/WBWDIGDF2016Jul/ world-development-indicators-wdi-august-2016?tsId=1792150 (accessed on 31 August 2017).

92. IEA Statistics. Available online: http:/ / www.iea.org/statistics/ (accessed on 31 August 2017).

93. Statistical Yearbook Okinawa. Available online: http://www.pref.okinawa.jp/toukeika/yearbook/ yearbook_index.html (accessed on 31 August 2017). 
94. SSB Statistics. Table 08809. Available online: https://www.ssb.no/en/table/08809 (accessed on 31 August 2017).

95. Self-Sufficiency Production Based on Statistics Provided by the Ministry of Agriculture, Forestry and Fisheries. Available online: http://www.maff.go.jp/j/zyukyu/zikyu_ritu/attach/pdf/zikyu_10-3.pdf (accessed on 31 August 2017).

96. National Data. Available online: https://www.regjeringen.no/en/topics/food-fisheries-and-agriculture/ mat/innsikt/matsikkerhet/id2357158/ (accessed on 31 August 2017).

97. Statistical Yearbook of Okinawa. Available online: http://www.pref.okinawa.jp/toukeika/yearbook/ yearbook_index.html (accessed on 31 August 2017).

98. Norwegian Institute for Agro-Economics. Available online: http:/ / nilf.no/publikasjoner/Notater/2015/ verdiskaping_i_landbruk_og_landbruksbasert_verksemd_i_sogn_og_fjordane(accessed on 28 August 2017).

99. Statistical Yearbook Okinawa. Available online: http://www.pref.okinawa.jp/toukeika/yearbook/59/ yearbook59.html (accessed on 31 August 2017).

100. SSB statistics. Table 07979. Agriculture, Forestry \& Fisheries (Residence). Available online: https:/ / www. ssb.no (accessed on 31 August 2017).

101. Based on Average Farm Income in Japan. In Statistical Yearbook Japan; Available online: http:/ / www.stat.go. jp/english/ (accessed on 31 August 2017).

102. Estimation Based on Agricultural Income for Average Farm in Norway, Data from Statistics Norway. Available online: https:/ / www.ssb.no (accessed on 31 August 2017).

103. Estimate does not Include Food Processing. In Statistical Yearbook Okinawa; Available online: http://www. pref.okinawa.jp/toukeika/yearbook/59/yearbook59.html (accessed on 31 August 2017).

104. Statistics Norway. Estimation Based on Number of Farmers in Sogn og Fjordane and Their Income. Available online: https:/ / www.ssb.no (accessed on 31 August 2017).

105. Ishihara, M.; Hoshino, E.; Fujita, Y. Self-determinable Development of Small Islands; Springer: Singapore, 2016; p. 19, doi:10.1007/978-981-10-0132-1.

106. Statistics Norway. Estimation Based on Data for Gross Fixed Capital Formation and Output at Current Prices. Available online: https:/ / www.ssb.no (accessed on 31 August 2017).

107. National Food and Agriculture Research Organisation Japan. Available online: https:/ /www.naro.affrc.go. jp/english/research/320/030227.html (accessed on 31 August 2017).

108. Mano, H.; Takeda, F.; Kitamura, T.; Okamoto, S.; Suzuki, Y.; Park, C.B.; Minamiyama, M. Water Quality Comparison of Secondary Effluent and Reclaimed Water to Ambient River Water of Southern Okinawa Island via Biological Evaluation. Environ. Monit. Assess. 2017, 189, 442, doi:10.1007/s10661-017-6160-7.

109. Okinawa Prefecture. Long-Term Water Demand and Supply Plan for Okinawa. 2010. Available online: http:/ / www.pref.okinawa.jp/site/kikaku/chiikirito/chiikishinko/kentyoukimizujyukyukeikaku. html (accessed on 1 September 2017).

110. ISEP: Renewables Japan Status Report 2016. Available online: http://www.isep.or.jp/en/wp/wp-content/ uploads/2016/10/JSR2016Summary-EN.pdf (accessed on 31 August 2017).

111. Ministry of Agriculture, Forestry and Fisheries Japan. Available online: http://www.maff.go.jp/j/zyukyu/ zikyu_ritu/zikyu_10.html (accessed on 31 August 2017).

112. Grilli, G.; De Meo, I.; Garegnani, G.; Paletto, A. A multi-criteria framework to assess the sustainability of renewable energy development in the Alps. J. Environ. Plan. Manag. 2016, 60, 1276-1295, doi:10.1080/09640568.2016.1216398.

113. Bernués, A.; Rodríguez-Ortega, T.; Alfnes, F.; Clemetsen, M.; Eik, L.O. Quantifying the multifunctionality of fjord and mountain agriculture by means of sociocultural and economic valuation of ecosystem services. Land Use Policy 2015, 170-178, doi:10.1016/j.landusepol.2015.05.022.

114. United Nations Framework Convention on Climate Change. A/RES/48/189. 1994. Available online: http:/ / www.refworld.org/docid/3b00f2770.html (accessed on 3 September 2017).

115. EUROSTAT. Available online: http:/ / ec.europa.eu/eurostat/ (accessed on 3 September 2017).

116. UN Working Group on Big Data. Available online: https://unstats.un.org/bigdata/ (accessed on 3 September 2017). 
117. Global Partnership for Sustainable Development Data. Available online: http://www.data4sdgs.org/ (accessed on 3 September 2017).

118. Gapminder. Available online: https:/ /www.gapminder.org/ (accessed on 2 September 2017).

119. Weitz, N.; Strambo, C.; Kemp-Benedict, E.; Nilsson, M. Closing the governance gaps in the water-energy-food nexus: Insights from integrative governance. Glob. Environ. Chang. 2017, 45, 165-173, doi:10.1016/j.gloenvcha.2017.06.006.

(C) 2017 by the authors. Licensee MDPI, Basel, Switzerland. This article is an open access article distributed under the terms and conditions of the Creative Commons Attribution (CC BY) license (http:// creativecommons.org/licenses/by/4.0/). 